Schulich School of Law, Dalhousie University

Schulich Law Scholars

Articles, Book Chapters, \& Blogs

Faculty Scholarship

$9-23-2020$

\title{
Wrongful Extradition: Reforming the Committal Phase of Canada's Extradition Law
}

Robert Currie

robert.currie@dal.ca

Follow this and additional works at: https://digitalcommons.schulichlaw.dal.ca/scholarly_works

Part of the Criminal Law Commons, and the Human Rights Law Commons

\section{Recommended Citation}

Robert J Currie, "Wrongful Extradition: Reforming the Committal Phase of Canada's Extradition Law" (23 September 2020), online: SSRN, < https://ssrn.com/abstract=3664754 > [https://perma.cc/VPE8-XR2J].

This Article is brought to you for free and open access by the Faculty Scholarship at Schulich Law Scholars. It has been accepted for inclusion in Articles, Book Chapters, \& Blogs by an authorized administrator of Schulich Law Scholars. For more information, please contact hannah.steeves@dal.ca. 


\title{
Wrongful Extradition: Reforming the Committal Phase of Canada's Extradition Law
}

\author{
R O B E R T J C URR I E*
}

\begin{abstract}
There has recently been an upswing in interest around extradition in Canada, particularly in light of the high-profile and troubling case of Hassan Diab who was extradited to France on the basis of what turned out to be an ill-founded case. Diab's case highlights some of the problems with Canada's Extradition Act and proceedings thereunder. This paper argues that the "committal stage" of extradition proceedings, involving a judicial hearing into the basis of the requesting state's case, is unfair and may not be compliant with the Charter and that the manner in which the Crown conducts these proceedings contributes to this unfairness. It also argues that regardless of the Act's constitutionality, in light of Diab and other disturbing cases, the time is ripe for law reform to ensure that
\end{abstract}

* Professor of Law, Schulich School of Law, Dalhousie University. I am grateful to the participants in the "Halifax Colloquium on Extradition Law Reform," which was held at the MacEachen Institute for Public Policy \& Governance, Dalhousie University, in September 2018, hosted by Professor Kevin Quigley and Rachel Cadman. The Colloquium was funded by the Canadian Partnership on International Justice (CPIJ), under a grant provided by the Social Sciences and Humanities Research Council of Canada (SSRHC), and I thank Professor Fannie Lafontaine and M. Érick Sullivan for their support. I am also grateful to: Laura Ellyson, doctoral student at the Schulich School of Law, who provided research support and acted as rapporteur to the Colloquium; Olivia Genge, Lee Ann Conrod, and Nicholas Hooper for research assistance; and Andrew Martin, Neil Boister, Joseph Rikhof, Joanna Harrington, and Maeve McMahon for their comments. Unless otherwise indicated, all views expressed here are my own. 


\section{MANitoba LAW JOURNAL}

extradition proceedings are carried out in a way that is consistent with Canadian public policy. Some suggestions for reform are made, as well as a proposal for a serious Parliamentary effort.

Keywords: extradition; international law; Charter of Rights and Freedoms; transnational crime; International Assistance Group; Crown law

\section{INTRODUCTION}

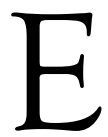

xtradition - the formal surrender of individuals between states in order to facilitate criminal proceedings - is often thought of as an obscure legal process, despite its reputedly ancient origins. ${ }^{1}$ This is no less true in Canada where the relatively small number of extradition cases are handled predominantly by lawyers in Justice Canada's International Assistance Group (IAG) ${ }^{2}$ and a smattering of defence lawyers across the country, most of the latter of whom do not practice enough in the field to develop any particular expertise. The Canadian legal literature on extradition is not voluminous.

However, the veil of obscurity has been yanked open in the last several years. Internationally, extradition has been front and centre, from a proposed extradition law that sparked months of rioting and civil unrest in Hong Kong ${ }^{3}$ to Julian Assange's futile years-long attempt to avoid the British extradition hearing under way at the time of writing (which may see him extradited to face American wrath over the Wikileaks disclosures). ${ }^{4}$ For Canada's part, the arrest of Huawei CFO Meng Wanzhou in December 2018 on an American extradition warrant has embroiled it in what is easily

Ivan Shearer, Extradition in International Law (Manchester: Manchester University Press, 1971) at 5.

2 See Section II.C, below.

3 "Hong Kong: Timeline of extradition protests", BBC News (4 September 2019), online: <www.bbc.com/news/world-asia-china-49340717> [perma.cc/MD68-J5FZ]. See also "Canada suspends extradition treaty with Hong Kong over new security law", CBC News (3 July 2020), online: <www.cbc.ca/news/politics/canada-suspending-extradition-treatyhong-kong-over-security-law-1.5636479> [perma.cc/B7LG-R866] (Canada recently "suspended" its extradition treaty with Hong Kong as a means of protesting the new security law imposed upon it by China).

4 "Julian Assange appears in dock as extradition hearing resumes", BBC News (7 September 2020), online: <www.bbc.com/news/uk-54060427> [perma.cc/P4UV-8D3 P]. 
the most complex and daunting foreign policy dispute it has faced in decades $^{5}$ and put our extradition relations firmly on the public radar.

Even aside from the Meng case, however, Canada's extradition laws have increasingly come under scrutiny in the last several years by way of a slowly-building groundswell of unease around the mechanics and application of the 1999 Extradition Act. ${ }^{6}$ An early and prescient critique by Professor Anne La Forest suggested that while the then-"new" Act was certainly capable of achieving the Crown's stated goals of making Canada's extradition process more efficient and easier to access by partner states, it had also greatly reduced the role of the courts and focused too much power and discretion in the hands of the executive (specifically, the Minister of Justice). ${ }^{7}$ Over the course of two decades, and even in the face of (mostly unsuccessful) constitutional challenges, this forecast has proven to be true, and there have been growing calls for reform of the Extradition Act - a piece of legislation that frequent extradition commentator Gary Botting has called (perhaps hyperbolically) "the least fair law in Canada."

This unease came to a head during 2018-2019, during which time there was intense public interest in the case of Dr. Hassan Diab. Diab, a Canadian citizen of Lebanese descent, was extradited to France in 2014 to face terrorism charges, only to be released more than three years later when (as had been apparent during the Canadian extradition proceedings) the French case against him was exposed as being without foundation. This controversial case sparked calls for reform, which will be explored below.

More recently, a highly-criticized extradition case ended in the death of the individual sought. The leading recent extradition decision by the Supreme Court of Canada, MM $v$ United States of America, ${ }^{9}$ dealt with an extradition request by the U.S. for Michele Messina, a dual Canadian-U.S. citizen who fled the state of Georgia with her children in 2010 for fear of

5 See Charles-Louis Labrecque, "Canada-China Relations Since Meng Wanzhou's Arrest" (3 December 2019), online: Asia Pacific Foundation of Canada <www.asiapacific.c a/publication/canada-china-relations-wanzhous-arrest> [perma.cc/7BHW-NX38].

6 Extradition Act, SC 1999, c 18 [Act].

7 Anne Warner La Forest, "The Balance Between Liberty and Comity in the Evidentiary Requirements Applicable to Extradition Proceedings” (2002) 28:1 Queen's LJ 95 (QL).

8 Elyse Skura, "Nunavut priest sex abuse case stirs up criticism of 'least fair law in Canada”, CBC News (22 February 2019), online: <www.cbc.ca/news/canada/ottawa/e xtradition-france-canada-diab-rivoire-1.5028783> [perma.cc/LC2K-7AHZ].

$9 \quad \mathrm{MM} v$ United States of America, 2015 SCC 62 [MM]. 


\section{MANITOBA LAW JOURNAL}

her abusive husband. ${ }^{10}$ After she was arrested at a women's shelter in Quebec, she fought extradition for nine years. In its 2015 decision, a majority of the Supreme Court of Canada upheld her surrender despite clear evidence that had the conduct occurred in Canada, she would have a defence of necessity available, but that the defence was not available in the U.S. This, the Court ruled, was a matter for the foreign trial court. ThenJustice Minister Jody Wilson-Raybould agreed to re-consider the case but eventually confirmed the surrender order, and the Supreme Court denied leave to appeal on the confirmed order on October 17, 2019. ${ }^{11}$ Messina died by suicide in prison three weeks later, ${ }^{12}$ bringing her case to a dramatic and troubling close.

Extradition from Canada, ${ }^{13}$ as will be explained below, is a three-phase process. This article will focus on the second "judicial" or "committal" phase and argue that Canada's law and procedures are in need of significant reform. Changes are required, not because extradition itself is somehow illegitimate, but because our extradition machinery has a number of problematic features that produce unfairness, both systemically and in individual cases.

The rest of this paper will proceed in five parts. Part II will give an overview of the Diab case and explain how it, in particular, has provided impetus for reform efforts. Part III provides a brief overview of extradition law and procedure in Canada to set the backdrop for the reform proposals. Part IV will critique the law and procedure that underpin the committal phase and offer suggestions for change, while Part $\mathrm{V}$ will give similar treatment to the manner in which the Crown's role in extradition is conceived and executed. Reference to specific cases, particularly Diab and

10 Some background about the case can be found in Matthew Behrens, "Canada's extradition law a dangerous back-door bludgeon for abusive ex-spouses" (14 December 2018), online: rabble.ca <rabble.ca/columnists/2018/12/canadas-extradition-law-dange rous-back-door-bludgeon-abusive-ex-spouses> [perma.cc/XA5Z-62GA].

11 Michele Marie Mulkey aka Michele Marie Messina v Minister of Justice of Canada on behalf of the United States of America, 2019 CarswellQue8803, 2019 CarswellQue8804 (SCC).

12 Verity Stevenson, "Quebec mother who was to be extradited to U.S. on custody charge dies in Laval jail”, CBC News (7 November 2019), online: <www.cbc.ca/news/canada/ montreal/quebec-mother-to-be-extradited-us-dies-in-jail-1.5351567> [perma.cc/DT9PWNAD]; Matthew Behrens, "An act of institutional femicide: Remembering the life of Michele M" (21 November 2019), online: rabble.ca <rabble.ca/columnists/2019/11/act -institutional-femicide-remembering-life-michele-m> [perma.cc/22JX-C3WA].

13 Part 3 of the Extradition Act, which deals with extradition to Canada, will not be examined here. 
MM, will be made where useful, though comprehensive treatment must be sacrificed for brevity's sake. Part VI will offer conclusions and suggestions for further work.

\section{France V Diab: The CASE That MaKes the CASE FOR REFORM}

Prior to the Meng case, Hassan Diab's was probably the only extradition case that could truly be said to have captured substantial attention among Canadians. Detailed accounts can be found in a thorough academic article, ${ }^{14}$ numerous media stories, ${ }^{15}$ and most importantly a 124-page external review by former Ontario Deputy Attorney General Murray Segal, which was commissioned by the Justice Minister. ${ }^{16}$ In brief, the Ottawa sociology professor was arrested on an extradition warrant in November 2008, sought by France as the alleged perpetrator of the bombing of a Paris synagogue in 1980. Initially detained, he was released on extremely restrictive bail conditions, including the imposition of an electronic bracelet costing $\$ 2,000.00$ per month for which he had to pay. "Justice for Hassan Diab," a volunteer organization, was formed to fundraise for his bail and defence, and to lobby for staying the case and reform of Canada's extradition laws. ${ }^{17}$

From the outset, Diab maintained that he was the victim of mistaken identity and had been in Lebanon at the time of the bombing. He was eventually represented by distinguished Ottawa defence lawyer Don Bayne, and the case was fought fiercely by both Bayne and the IAG lawyers, to the extent that the judge at the committal hearing was moved to comment on

14 Maeve W. McMahon, "The Problematically Low Threshold of Evidence in Canadian Extradition Law: An Inquiry into its Origins; and Repercussions in the Case of Hassan Diab" (2019) 42:3 Man LJ 303.

15 See e.g. Amanda Connolly, "Who is Hassan Diab and why was his extradition so controversial?”, Global News (26 July 2019), online: <globalnews.ca/news/5682551/has san-diab-extradition-report/> [perma.cc/74D3-GF65].

16 Canada, Department of Justice, Independent Review of the Extradition of Dr. Hassan Diab (Report), by Murray D. Segal (Ottawa: DOJ, May 2019), online: <www.justice.gc.ca/> [perma.cc/9X9W-BQJY] [Segal Report].

17 Its website can be found here: "Justice for Hassan Diab: Preserve the Rights of Canadians Under Extradition Law" (last modified 9 February 2020), online: <www.justiceforhassandiab.org/> [perma.cc/S2K6-2U5S]. 


\section{MaNitoba LaW JOURNAL}

its intensity. ${ }^{18}$ Diab's defence centred on the weakness of the case presented by France, which essentially rested on a highly-contested handwriting analysis. Judicial decisions in the course of the proceeding featured several now-infamous dicta. The judge who presided over the committal hearing described the French case as being so weak that if Diab received a fair trial in France, he would likely be acquitted-but that nonetheless, Canada's extradition law required that he be surrendered. ${ }^{19}$ Affirming both the committal decision and the decision by the Minister of Justice to surrender Diab, the Ontario Court of Appeal dismissed concerns that the French case was not even ready for trial, remarking that Diab clearly would "not simply 'languish in prison."'20

After being extradited, Diab did indeed "simply languish" for more than three years, mostly in solitary confinement, in a maximum-security prison while the French investigation continued. He was released - without ever being committed for trial - when it became clear that the case had foundered completely, and what evidence there was indicated that Diab was not the bomber. ${ }^{21}$ Diab's return to Canada in January 2018 sparked renewed criticism from the Justice for Hassan Diab organization, now joined by others including Amnesty International, the British Columbia Civil Liberties Association (both of which had intervened in the original appeal), and the International Civil Liberties Monitoring Group. Controversy increased when media reporting revealed that Canadian officials had withheld exculpatory evidence and actively assisted French officials in shoring up the foundering French case. ${ }^{22}$ A group of academics, defence lawyers, and representatives from human rights organizations convened a colloquium to formulate a set of reform proposals, which is expected to be published in the future. ${ }^{23}$

Calls for examination of how extradition had gone so wrong drew concern from the Minister of Foreign Affairs, Chrystia Freeland, who disclosed that both she and the Prime Minister had pressed France to return

\footnotetext{
France (Republic) v Diab, 2011 ONSC 337 at para 193 [Diab Sup Ct]. Ibid at para 191.

France (Republic) v Diab, 2014 ONCA 374 at para 176 [Diab CA].

Segal Report, supra note 16 at 70-71.

This was confirmed in Segal Report, supra note 16. See section IV, below.

See Changing Canada's Extradition Laws: The Halifax Colloquium's Proposals for Law Reform [forthcoming, copy on file with author]. Disclosure: I was the convenor and chair of the Colloquium.
} 
Diab. ${ }^{24}$ Prime Minister Justin Trudeau stated that "what happened to [Diab] should never have happened," and promised that the federal government would "make sure this never happens again." ${ }^{25}$ However, this promise was eventually dissipated by the Segal Report which concluded that while Diab's case had seen some unfortunate events, all relevant laws and policies had been followed and all Crown personnel had acted appropriately. ${ }^{26}$

A criminal prosecution that results in an innocent person being convicted is referred to as a "wrongful conviction." In Hassan Diab's case, an extradition proceeding led to a demonstrably innocent person being extradited to face a faulty foreign criminal process, in a case where the Prime Minister of Canada stated that extradition "should never have happened." The only sensible descriptive phrase for this is "wrongful extradition," and that is the term that will be used in this paper. The critique here is based on the simple premise that an extradition system that allowed the wrongful extradition of Hassan Diab to occur must be in need of reform. This need is made all the more pressing by the fact that, as discussed in Part V below, the government authorities in charge of extradition are explicitly and publicly of the view that no reform is needed and that Diab's extradition to France was marred only by the fact that it took so long.

\section{THE CURRENT CANADIAN SCHEME FOR EXTRADITION}

\section{A. The International Law Backdrop: Sovereignty, Treaties, and Arrangements}

Extradition is the oldest and still one of the primary tools to accomplish the goal of inter-state cooperation in the suppression of crime generally, and transnational crime in particular. It has been defined as:

[T]he formal rendition of a criminal fugitive from a state that has custody (the requested state) to a state that wishes either to prosecute or, if the fugitive has

24 Jim Bronskill, "Justice Minister Wilson-Raybould orders independent review of Hassan Diab extradition case", National Post (30 May 2018), online: <nationalpost.com/news/p olitics/justice-minister-orders-external-review-of-hassan-diab-extradition-case $>$ [perma.cc /85XD-JAFJ].

25 David Cochrane \& Lisa Laventure, "Hassan Diab to boycott external review of 2014 extradition to France", CBC News (24 July 2018), online: <www.cbc.ca/news/politics/h assan-diab-boycott-external-review-france-extradition-1.4758418> [perma.cc/382M-F4F $\mathrm{N}$.

26 Segal Report, supra note 16 at $13-14$. 


\section{Manitoba LaW JOURnal}

already been convicted of an offence, to enforce a penal sentence (the requesting state). ${ }^{27}$

Extradition is made necessary by a fundamental rule of customary international law that prohibits states from enforcing their laws on the territories of other states. ${ }^{28}$ In the criminal sphere, this means that police cannot investigate or effect arrests outside their own country. Accordingly, in order for states to be able to prosecute individuals who leave or escape from their territories, ${ }^{29}$ they enter into agreements with foreign states under which each agrees to arrest and transmit the "fugitives" (now typically referred to as "persons sought") upon request and subject to certain conditions. The most standard practice is for states to enter into bilateral extradition treaties, which allows each government to carefully select the states with which it wishes to have such cooperation, in accordance with domestic priorities, human rights obligations, etc. Also, there are a number of multilateral crime suppression treaties, geared towards facilitating interstate cooperation around suppressing particular transnational crimes, which have extradition provisions. ${ }^{30}$

Canada is party to 51 bilateral extradition treaties ${ }^{31}$ and a large number of the crime suppression conventions that contain extradition provisions. A Schedule to the Extradition Act also designates certain states ${ }^{32}$ and

27 Robert J. Currie \& Joseph Rikhof, International $\mathbb{E}$ Transnational Criminal Law, 3rd ed (Toronto: Irwin Law, 2020) at 531. It is important to distinguish extradition from other legal means of removing individuals from a state, like immigration law-based mechanisms such as deportation or the expulsion of spies or foreign diplomats. Extradition relies explicitly on state-to-state agreements and is designed to facilitate criminal (and, increasingly, quasi-criminal/regulatory) prosecutions. It is a formal legal process with unique international and domestic law machinery. $R v$ Hape, 2007 SCC 26.

29 Or, at least, lawfully to do so. History is replete with examples of states simply abducting criminal fugitives from foreign states, which is a breach of international law. See Currie \& Rikhof, supra note 29 at 560-67.

30 Neil Boister, An Introduction to Transnational Criminal Law, 2nd ed (Oxford: Oxford University Press, 2018), c 20; Joanna Harrington, "Extradition of Transnational Criminals" in Neil Boister \& Robert J. Currie, eds, Routledge Handbook of Transnational Criminal Law (London: Routledge, Taylor \& Francis Group, 2015) 153.

31 Reasonably current compiled lists can be found at Halsbury's Laws of Canada (online), Extradition $\mathcal{E}$ Mutual Legal Assistance, "Introduction: Extradition Partners" (I.2) at HEX2 "Creation of Extradition Obligation" (2019 Reissue); Seth Weinstein \& Nancy L. Dennison, Prosecuting and Defending Extradition Cases: A Practitioner's Handbook (Toronto: Emond Publishing, 2017) at 15-16.

32 Most of which are Commonwealth states, including the United Kingdom. 
entities $^{33}$ as "extradition partners," which unlocks Canada's extradition machinery for those states/entities in the same manner as a treaty does. Most commonly, Canada makes and receives extradition requests via its bilateral treaties, particularly with the U.S. ${ }^{34}$ which unsurprisingly sees the most traffic of any of the treaties.

While the treaties do not play a large role in this article, it is worth noting that, constitutionally, they are strictly the preserve of the federal executive, and "that neither Parliament nor the provincial legislatures need, as a matter of law, to be consulted before the Crown binds Canada to an international agreement." 35 So far as can be seen from the rather paltry public sources on point, ${ }^{36}$ decisions on whether to negotiate extradition treaties are formally made via consultations between the Minister of Justice and the Minister of Foreign Affairs, and negotiations are conducted by officials within those two departments. Since the introduction of the federal treaty tabling policy in 2008, it appears that treaties are at least tabled in the House of Commons but do not attract debate; ${ }^{37}$ nor are the explanatory memoranda which are meant to accompany them ever published. ${ }^{38}$

33 Specifically, the International Criminal Court and the UN International Criminal Tribunals for the Former Yugoslavia and Rwanda.

34 Treaty on Extradition between the Government of Canada and the Government of the United States of America, United States and Canada, 3 December 1971, Can TS 1976 No 3 (in force 22 March 1976), as amended by Protocol 1, 11 January 1988, CTS 1991 No 37 (in force 26 November 1991) and Protocol 2, 12 January 2001, Can TS 2003 No 11 (in force 30 April 2003) [Canada-US Treaty].

35 Phillip M. Saunders et al, Kindred's International Law: Chiefly as Interpreted and Applied in Canada, 9th ed (Toronto: Edmond Publishing, 2019) at 155.

36 A modest amount of information can be found at Canada, Department of Justice, About the International Assistance Group (Ottawa: DOJ, last modified 20 October 2016), online: <www.justice.gc.ca/eng/cj-jp/emla-eej/about-apropos.html> [perma.cc/L222-XHYN].

37 "Bill C-4, An Act respecting non-for-profit corporations and certain other corporations", 2nd reading, House of Commons Debates, 40-2, No 010 (6 February 2009) at 1200 (Hon Lawrence Cannon), online: <www.ourcommons.ca/DocumentViewer/e n/40-2/house/sitting-10/hansard> [perma.cc/5LTK-M2RD] (Foreign Affairs Minister Lawrence Cannon tabled a new Canada-Italy extradition treaty, without any comment being made).

38 Gib Van Ert has commented that "Canada's practices in the conclusion and domestic performance of treaties remains scandalously opaque". See Gib Van Ert, "POGG and Treaties: The Role of International Agreements in National Concern Analysis" (8 June 2020), online (blog): Gib Van Ert <gibvanert.com/2020/06/08/the-role-of-internationa l-agreements-in-national-concern-analysis/> [perma.cc/99MU-6J7K]. 


\section{MANitOBA LAW JOURNAL}

It is worth highlighting, then, that extradition proceedings will necessarily deprive individuals (including Canadian citizens) of their liberty, at the hands of both the Canadian government and a foreign state; yet no meaningful public consultation has ever been conducted by the government as to whether we should have extradition treaties with particular states, nor what conditions should be placed on extraditions completed under those treaties. Even Prime Minister Trudeau's sudden announcement in September 2016 that Canada would begin negotiating an extradition treaty with China seemed to emerge from some government back room and only saw any debate because it was so publicly controversial. ${ }^{39}$

\section{B. The Extradition Act 1999}

Extradition treaties (like all treaties) are not automatically part of Canadian law but must be implemented by way of statute. In the case of extradition, the Extradition Act implements all of Canada's extradition arrangements and provides a "complete code" of procedure for extradition to and from Canada. Prior to 1999, extradition was completed under two different statutes: the old Extradition Act, which was modelled on the British statute, and the now-repealed Fugitive Offenders Act, which contained a streamlined extradition process for Commonwealth partners. The current Act was brought in as an effort to address what the federal government identified as inefficiencies and difficulties in Canada's ability to extradite to foreign states. A particular problem was said to be issues faced by foreign states with civil justice systems, which had difficulty meeting the evidentiary requirements of the Canadian legislation - to the point where some partner states were discouraged from making requests at all. ${ }^{40}$ Generally speaking, the goal was to replace Canada's "antiquated" extradition system in order to respond to the new realities of transnational crime and, rhetorically at least, ensure Canada did not become a haven for criminals.

The new legislation was explicitly designed to create a more streamlined and simplified "three-phase process" for extraditions from Canada: (1) the

39 Steven Chase \& Robert Fife, "Justin Trudeau defends extradition treaty talks with China", The Globe and Mail (21 September 2016), online: <www.theglobeandmail.com /justin-trudeau-defends-extradition-treaty-talks-with-china> [perma.cc/ZR7S-JQFB].

40 Elaine F. Krivel et al, A Practical Guide to Canadian Extradition (Toronto: Carswell, 2002) at 11. An excellent account of how the new Act was ushered in can be found in McMahon, supra note 14. McMahon notes, in particular, that while there was little doubt that the procedural machinery needed updating, the evidence of problems experienced by requesting states was overstated. 
"Authority to Proceed" (ATP); (2) judicial committal or discharge; and (3) ministerial surrender or refusal to surrender for extradition. ${ }^{41}$ The front end of the process is the ATP phase in which lawyers at the IAG receive and evaluate the extradition request to ensure it complies with the relevant treaty and, in particular, that the offence for which the individual is sought is an extraditable offence. The latter point requires that there be "double criminality" (i.e., that the offence involved is one that is punishable up to a certain threshold by both Canada and the requesting state). ${ }^{42}$ The Canadian offence that corresponds to the foreign offence must be explicitly identified. The ATP itself is issued by the Minister and empowers staff counsel to, inter alia, have the individual arrested and seek an order "committing" them for extradition.

The committal phase, which is the focus of this article, requires a hearing before a superior court judge who will essentially decide two things: (1) whether the person before the court is actually the person sought and (2) whether the evidence that has been presented by the requesting state would be sufficient to have a person committed for trial in Canada (for the Canadian offence identified in the ATP) if the conduct had occurred in Canada. ${ }^{43}$ While, historically, the requesting state would have had to actually adduce evidence that made out a prima facie case, the 1999 Act brought in an innovation: requesting states are permitted to submit a "Record of the Case" (ROC) which is essentially a summary of the evidence underpinning the request. It must be accompanied by the certification of a judicial or prosecuting authority of the requesting state, to the effect that the evidence summarized is indeed available for trial, and either is sufficient under that state's law to justify prosecution or was gathered in accordance with that state's law. ${ }^{44}$ This provision was seemingly designed to accommodate states (primarily from civil law traditions ${ }^{45}$ ) whose evidentiary

41 See MM, supra note 9 at paras $16-26$.

42 Either a minimum of two years imprisonment under section 3 of the Act or whatever the governing treaty says-for example, Article 2 of the Canada-US Treaty, supra note 36, provides for extradition where the offence is punishable by one year or more of imprisonment.

43 Act, supra note 6, s 29(1)(a).

44 Act, supra note 6, s 33.

45 There is a similar regime specifically provided for in the Canada-France extradition treaty, which pre-dates the Act. See Extradition Treaty between the Government of Canada and the Government of the Republic of France, Canada and France, 17 November 1988, Can TS 1989 No 38 (in force 1 December 1989), art 10(2)(c). 


\section{MANITOBA LAW JOURNAL}

regimes were dissimilar to Canada's and who would otherwise not be able easily to produce a prima facie case based on evidence. However, it was quickly adopted as the desirable approach by the U.S., Canada's most frequent requesting state, and now is used in the majority of cases. ${ }^{46}$ The ROC regime also spares the requesting state the need to present evidence in court, particularly viva voce evidence which is expensive and timeconsuming. The result is that the ROCs contain what Canadian lawyers would call hearsay, unsworn statements and otherwise unsubstantiated evidence.

The role of the committal judge is similar to, but more expansive than, that of a preliminary inquiry judge. ${ }^{47}$ The sufficiency of evidence test under paragraph 29(1)(a) still assesses whether the evidence shows a prima facie case, albeit with relaxed evidentiary rules, and the judge must engage in a "limited weighing" of the evidence (or, more accurately, the summary of the evidence, assuming the ROC to be true) to determine whether a reasonable jury, properly instructed, could convict on the evidence. Importantly, under the Act, the evidence in the ROC is presumed to be reliable, ${ }^{48}$ and while the individual sought is permitted to challenge the evidence (either individual items or in its entirety) on the basis of reliability, they bear the overall onus of rebutting this presumption (paragraph 32(1)(a)). In turn, that rebuttal will only be successful where the person sought demonstrates that the evidence is "manifestly unreliable." 49 More will be said about this below.

If the person is committed for extradition, the process enters the "surrender phase" where the Minister of Justice makes the final decision on whether the individual will be extradited. ${ }^{50}$ This task has consistently been described by the Supreme Court as "essentially political in nature," ${ }^{51}$ in that the Minister is primarily concerned with discharging Canada's treaty relevant extradition treaty per paragraph 32(1)(b) of the Act, supra note 6. However, it must still establish that the evidence exists and is available for trial (United States $v$ Ferras, 2006 SCC 36 at paras 57-58 [Ferras]; United Mexican States v Ortega, 2006 SCC 34).

47 Weinstein \& Dennison, supra note 33 at 215. See also Act, supra note 6, s 24(2).

48 Ferras, supra note 48 at paras 52-56.

49 United States $v$ Prudenza (sub nom Anderson), 2007 ONCA 84 at para 31 [Anderson], cited in MM, supra note 9 at para 72 .

Act, supra note 6, s 40.

MM, supra note 9 at para 25. 
obligations as "a responsible member of the international community." While the decision must be Charter-compliant, it is one that is on "the extreme end of the... scale" and attracts an extremely deferential standard of review..$^{53}$ This is because the Minister is exercising their capacity under the Crown prerogative over foreign affairs, and the courts choose to be circumspect. Sections 44 and 46 to 47 of the Act set out a number of grounds on which the Minister can refuse surrender, some of which are mandatory and more of which are discretionary.

Finally, it is well-established in the Supreme Court's jurisprudence that the Charter applies to the entire extradition process. The Court's preferred analytical lens has been section 7, which bars the state from depriving an individual of liberty "except in accordance with the principles of fundamental justice", and it has developed a set of such principles that are tailored to both the committal ${ }^{54}$ and ministerial ${ }^{55}$ phases (the former of which will be dealt with here).

Committal decisions are subject to appeal, ${ }^{56}$ and surrender decisions to judicial review, ${ }^{57}$ before the relevant provincial court of appeal, and both can end up at the Supreme Court for final disposal if granted leave. In many cases, both committal and surrender are challenged, and the standard practice is to combine both appeal and judicial review into a single hearing at both levels of court. ${ }^{58}$

\section{The Role of the International Assistance Group}

The IAG is a specialized division of Justice Canada which "was established to carry out most of the responsibilities assigned to the Minister of Justice under the Extradition Act and the Mutual Legal Assistance in Criminal Matters Act." ${ }^{59}$ IAG acts as Canada's "central authority" ${ }^{60}$ for all of

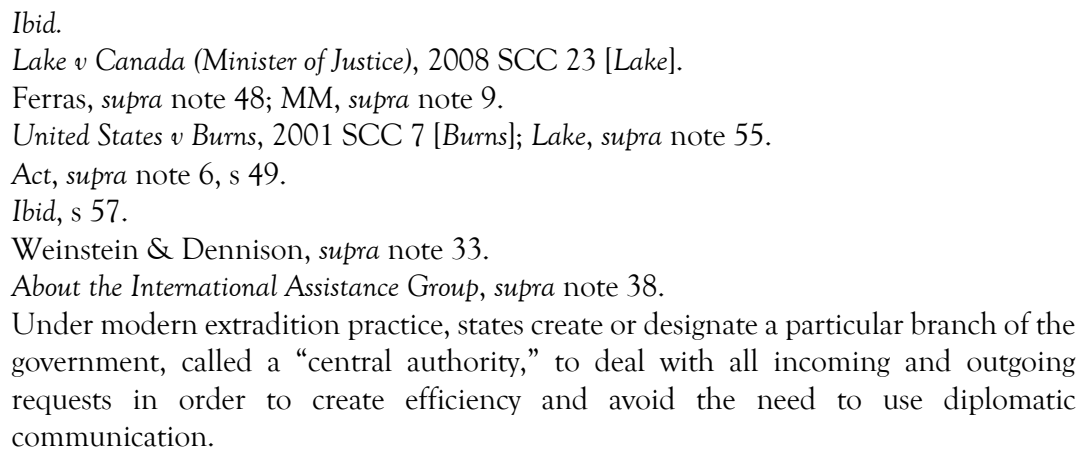
government, called a "central authority," to deal with all incoming and outgoing requests in order to create efficiency and avoid the need to use diplomatic communication. 


\section{MANITOBA LAW JOURNAL}

Canada's international criminal cooperation activities and administers the government's communication and cooperation with foreign states in this regard. So far as extradition goes, the IAG plays a number of roles: it develops extradition treaty relationships; it fields incoming requests from foreign states, as well as consulting and assisting them, and also presides over outgoing communication and requests; it obtains evidence "for use at home or abroad, including for use in extradition"; ${ }^{61}$ it advises regional Canadian counsel on international cooperation methods; and it approves and issues the ATP in appropriate cases.

Most important for present purposes, IAG personnel conduct the litigation in the adversarial extradition proceedings. They do this either indirectly, by advising and instructing litigation counsel employed by Justice Canada ${ }^{62}$ or, in some cases, acting as counsel in those proceedings ${ }^{63}$ - which is to say, they act as counsel for the requesting states. They also advise the Minister on all aspects of extradition proceedings, up to and including the drafting of Ministerial surrender decisions. ${ }^{64}$ In fundamental terms then, IAG adversarially "prosecutes" the extradition case on behalf of the Crown and, ultimately, the requesting state; makes the final decision regarding surrender; and fights any appeals or judicial reviews in court. This remarkable dominance of the entire process by a government agency will examined in Part V below.

\section{THE JUDICIAL TASK AND ISSUES AT THAT COMMITTAL STAGE}

\section{A. The Primary Problem: Legislative Interpretation}

In $\mathrm{MM}$, the current leading case on the committal process, Justice Cromwell for the majority of the Court began the judgment by stating that "the extradition process serves two important objectives: the prompt compliance with Canada's international obligations to our extradition

61 Segal Report, supra note 16 at 34.

62 In British Columbia and Ontario, where the extradition traffic is highest, there are specialist Justice Canada practice groups set up for extradition and MLAT proceedings.

63 This occurred in Diab Sup Ct, supra note 20. The Segal Report presented this as "unusual" (supra note 16 at 19).

64 Formally speaking, this is a power that is reserved for the Minister, and the Minister personally makes the decision upon the advice of IAG and signs it. However, the decisions are in substance made by IAG lawyers. See Segal Report, supra note 16 at 65 . 
partners, and the protection of the rights of the person sought." ${ }^{65}$ On the current state of the law, however, there is an imbalance between these two "objectives." The Extradition Act is the driver of the "extradition process," and the courts have consistently found that its sole objective is to facilitate extradition. Protection of the rights of the person sought has been a secondary objective at best, de-emphasized by the Crown and applied only half-heartedly by the courts. From this standpoint, I will argue that the committal process is unfair.

In the course of two decades of caselaw regarding the committal process, the Crown has urged upon the courts - mostly successfully - two related themes: (1) that the primary interpretive principle the courts should apply to the Extradition Act is the safeguarding and promotion of international comity between Canada and its extradition partner states, and (2) that Parliament intended extradition to be an expeditious and summary process, informed as little as possible by Canadian criminal law fundamentals. I will briefly explain each of these in turn.

On the first theme, extradition, of course, is a tool of inter-state cooperation that has the single goal of suppressing transnational crime, and the achievement of this goal depends on states making effective use of extradition treaties and arrangements. The 1999 Act was explicitly drafted with this in mind, ${ }^{66}$ and thus it is not surprising that nearly every reported extradition decision makes reference to some variant of Canada maintaining "international comity" by being a good extradition partner. ${ }^{67}$ In fact, comity is basically the only interpretive principle that the courts, urged on by the Crown, have seen fit to use.

On the second theme, the Supreme Court and lower courts have constantly emphasized that extradition cannot be efficacious unless it is expeditious, and that expedition, in turn, requires the procedural machinery to be kept to a minimum. The most consistent expression of this emphasis is that, as the majority noted in MM, "the extradition process is not a trial and, as the Court said nearly three decades ago, it should never be permitted to become one." ${ }^{68}$ The committal process, in particular, is a

\footnotetext{
65 MM, supra note 9 at para 1.

66 Krivel et al, supra note 42 at 10-13.

67 United States v Dynar, [1997] 2 SCR 462 at para 122, 147 DLR (4th) 399.

68 MM, supra note 9 at para 2.
} 


\section{Manitoba LaW JOURNAL}

"modest screening device," ${ }^{69}$ and fairness in this process does not require a (criminal) trial. Instead, it simply requires "that there is sufficient evidence to justify putting the person on trial." 70

The procedural machinery will be explored below. As a preface point, however, this matrix of emphasis is perhaps to be expected since, despite the fact that the goal of the Act is to render people to face criminal trials, the process created is fundamentally a non-criminal, judicial-administrative law hybrid that incorporates certain criminal procedure machinery only by necessity. ${ }^{71}$ In roughly the same manner that a preliminary inquiry judge would do, the committal judge determines, essentially in the abstract, whether the evidence proffered by the requesting state would justify committal for trial in Canada. The presumption of innocence does not apply, and any questions regarding defences are left for the actual criminal trial to be held in the requesting state. The push and pull throughout the case law, however, reflects consistent effort by the defence bar to have the courts take into account that the entire ambit of the process is the deprivation of liberty of the person sought and to inject an appropriate amount of gravity and procedural protection into it - an effort that has been largely unsuccessful.

During the following examination of issues that are raised by the committal process, it is worth bearing in mind that the Crown's insistence on these two themes is fundamentally accurate. The structure of the Act and the way the process has played out supports the view that Parliament did indeed intend to provide for an expeditious process that was primarily geared toward making sure extradition requests were fulfilled. Of course, though Parliament held the pen, it was guided by the hand of Justice Canada which formulated the legislation and the policy goals that underpin it, steered the Act through the legislative process, and continues to negotiate and administer the treaties and determinedly pursue extradition, all with minimal public input. The Act is fundamentally a piece of law enforcement legislation because it was made by law enforcers. The question for Canadians is whether this is as it should be or whether change needs to be made.

Ibid at para 2; United States v Yang (2001), 56 OR (3d) 52 at paras 47, 64, 86, DLR (4th) 337 (ONCA), cited in MM, supra note 9 at paras 38, 53, 61.

MM, supra note 9 at para 61.

71 See Joanna Harrington, "Extradition, Assurances and Human Rights: Guidance from the Supreme Court of Canada in India v. Badesha” (2019) 88 SCLR (2d) 273. 


\section{B. Admissibility and Sufficiency of Evidence: Re- Invigorating Ferras}

\section{Changes to Committal Under the 1999 Act: From Shephard to MM}

To understand properly the central fairness issues with the committal process, it is important to review the changes made by the 1999 Act. In a detailed overview, Professor Anne Warner La Forest wrote that extradition law had always rested on maintaining a balance between safeguarding the liberty of the person sought and state interest in international cooperation. ${ }^{72}$ In Canada, historically the committal process had achieved this, more or less, by maintaining a procedural alignment between extradition proceedings and the preliminary inquiry; the committal hearing was in fact prescribed by the former legislation to be conducted "as nearly as may be" 73 to a preliminary inquiry. In keeping with the approach of most common law jurisdictions, the requesting state was required to present a prima facie case ${ }^{74}$ which, importantly, had to be based on evidence that was admissible under Canadian law. ${ }^{75}$ The trickiest point was around hearsay, to which common law jurisdictions like Canada took a restrictive approach but was used liberally in other states. Since the calling of live witnesses was too expensive and time-consuming to be justified or practical for extradition purposes, first-person sworn/affirmed statements or affidavits were admissible. However, second- and third-hand hearsay was not admissible, "ensur[ing] that the evidence is reliable and that the person giving it has received a warning that he or she must speak truthfully." 76

The test for committal, originally laid out US $v$ Shephard, ${ }^{77}$ was the same as that which governed preliminary inquiries: if there was evidence that offered some form of proof on each element of the offence (i.e. sufficiency), and assuming that evidence to be true (i.e. reliability), the judge asked whether a reasonable trier of fact, properly instructed, could find the accused guilty. The judge did not weigh the evidence, nor was the defence

72 La Forest, supra note 7.

73 Extradition Act, RS 1985, c E-23, s 13 (repealed by the Act, supra note 6, s 129).

74 See Geoff Gilbert, Transnational Fugitive Offenders in International Law: Extradition and Other Mechanisms (New York: Springer Publishing, 1998) at 119-27.

75 This included certain modest relaxations of Canadian evidence law in the old Act to accommodate the extradition setting.

$76 \quad$ La Forest, supra note 7 at para 57.

77 United States $v$ Shephard, [1977] 2 SCR 1067, 70 DLR (3d) 136. 


\section{MANITOBa LAW JOURNAL}

allowed to challenge its reliability. However, as Professor La Forest pointed out, this was unnecessary since the evidence was admissible under Canadian law and thus to assume its reliability was reasonable and fair. ${ }^{78}$ This structure allowed Canada to strike the balance between comity and the safeguarding of liberty - the trial system of the foreign state, which might be very different from Canada's, was not questioned or undermined, but Canada would only extradite a person where they could be put on trial in similar circumstances in Canada. This was, in fact, the substance of the double criminality principle.

The 1999 Act changed this machinery fundamentally, particularly with the introduction of the ROC. The policy justification often proffered was that providing evidence in a form admissible under Canadian law resulted in extradition being difficult or even impossible for requesting states which had civil law systems, not least because hearsay evidence was used extensively and the concept of sworn statements was not known to those systems. ${ }^{79}$ The solution was adopting the ROC which, as noted earlier, is a summary of evidence supporting the charge that is certified either to be available for trial in the requesting state or at least gathered in accordance with that state's law. The evidence described in the ROC is presumed reliable. The analogy to a preliminary inquiry was kept, subject to "any modifications that the circumstances require." 80

Importantly, the test for committal did not change and the Shephard test was essentially codified in paragraph 29(1)(a) of the Act. As Professor La Forest noted, this approach amounted to "retaining the prima facie standard but relaxing the admissibility standard." ${ }^{\prime 1}$ She argued that this upset the balance between liberty and comity in a way that de-legitimized the process:

The logic of Shephard in terms of reliability does not apply once admissibility is relaxed to the point of allowing second and third hand hearsay in one process and not in the other. It is true that under the new Act, the record of the case must be certified by a judicial or prosecuting authority in the requesting state, but that would not be sufficient to warrant admissibility of the evidence in Canadian proceedings. There is thus no longer an alignment between preliminary

La Forest, supra note 7 at para 72.

79 Both Professor La Forest and Professor McMahon are highly critical of the solidity of this rationale and the quality and amount of evidence which was put forward in support of it. See especially McMahon, supra note 14 where she carefully reviews the process of the Bill through Parliament.

80 Act, supra note 6, s 24(2).

$81 \quad$ La Forest, supra note 7 at para 103. 
proceedings and extradition proceedings in Canada. It was this balance that formed the basis for the statements in Charter decisions that the extradition hearing was generally in accordance with fundamental justice. If it is accepted that it is a basic tenet of our legal system that a person cannot be bound over for trial in this jurisdiction based upon the kind of evidence provided for in the new Act, then it can be postulated that, in general, it is contrary to fundamental justice to extradite a person, who may well be a Canadian national, to a requesting state based upon that evidence to face trial in that country. ${ }^{82}$

Essentially, Canada had gone from a system where committal should be ordered based on evidence that was admissible under Canadian law, to one where committal should be ordered based on the fact that evidence could be shown to exist even though that evidence would not necessarily have been admissible under Canadian law ${ }^{83}$ and could not realistically be tested. "Indeed," Professor La Forest memorably remarked, "other than as a matter of form, it is difficult to understand why the judicial role has been retained in the new Act, as the extradition judge has little, if anything, to do." ${ }^{84}$

For some years after the Act's coming into force, the Crown advanced the argument that the sufficiency test had not changed from Shephard and that, despite the changes regarding admissibility of evidence, the committal judge had no discretion to review, weigh, or evaluate the evidence put forward in the ROC. In a set of constitutional challenges led by the case of $R v$ Ferras ${ }^{85}$ however, the Supreme Court took up the substance of Professor La Forest's suggestion that the new Act had swung the balance over into unconstitutional territory. Noting that "[ $t]$ he Act is silent on whether the judge has a residual discretion to exclude evidence that is unreliable or dangerous," ${ }^{86}$ Chief Justice McLachlin for the Court held that using the preliminary inquiry structure as an analogue for the committal hearing could not, as a matter of "fundamental justice" under section 7 of the Charter, be pushed as far as the Shephard test permitted. It might be acceptable to deprive trial judges of the ability to weigh or evaluate evidence

$82 \quad$ Ibid at para 73.

83 As Botting notes, "[s]ince the summary of evidence set out in the record of the case is hearsay - if not double or triple hearsay - it clearly would not be 'admissible under Canadian law' except by virtue of section 32". See Gary Botting, "The Supreme Court 'Decodes' the Extradition Act: Reading Down the Law in Ferras and Ortega" (2007) 32:2 Queen's LJ 446 at 468 (QL).

84 La Forest, supra note 7 at para 130.

85 Ferras, supra note 48.

86 Ibid at para 37. 


\section{MANitoba LAW JOURNAL}

in the context of committal for trial in Canada because evidence was admitted in a preliminary inquiry "according to the domestic rules of evidence, with all of the inherent guarantees of threshold reliability that those rules entail." ${ }^{87}$ In the extradition context, however, this protection was not present, which would "deprive the subject of his or her constitutional right to a meaningful judicial determination before the subject is sent out of the country and loses his or her liberty." ${ }^{\prime 8}$ This, the Court ruled, was constitutionally infirm:

[T] he combined effect of the relevant provisions (ss. 29, 32 and 33 of the Act) may be to deprive the person sought of the independent hearing and evaluation required by the principles of fundamental justice applicable to extradition. If the extradition judge possesses neither the ability to declare unreliable evidence inadmissible nor to weigh and consider the sufficiency of the evidence, committal for extradition could occur in circumstances where committal for trial in Canada would not be justified. I take as axiomatic that a person could not be committed for trial for an offence in Canada if the evidence is so manifestly unreliable that it would be unsafe to rest a verdict upon it. It follows that if a judge on an extradition hearing concludes that the evidence is manifestly unreliable, the judge should not order extradition under s. 29(1). Yet, under the current state of the law in Shephard, it appears that the judge is denied this possibility. ${ }^{89}$

It is worth pausing at this point to observe that in support of these points, Chief Justice McLachlin pointedly cited Professor La Forest's criticism that the committal judges "have nothing left to do." 90 "The judge," she wrote, "becomes a rubber stamp." 11 One might conclude that this unconstitutional and unfair hollowing out of judicial process was, in fact, a deliberate product of the 1999 Extradition Act's design or, at the very least, a product of the Crown's litigation strategy in proceedings under the Act. ${ }^{92}$

To remedy the situation, the Court read down subsection 29(1) such that it granted the committal judge discretion "to refuse to extradite on insufficient evidence such as where the reliability of the evidence certified is successfully impeached or where there is no evidence, by certification or

$87 \quad$ Ibid para 48 .

$88 \quad$ Ibid at para 47.

89 Ibid at para 40.

$90 \quad$ La Forest supra note 7 at 172, cited in Ferras supra note 48 at para 41. The Court also cited similar remarks made by Gary Botting in Extradition Between Canada and the United States (Leiden: Martinus Nijhoff, 2005) at 8.

91 Ferras, supra note 48 at para 41.

92 This is borne out by a review of the Respondent Factum in Ferras, in which the Crown resolutely denied any Charter or fairness issues with these provisions. See United States of America v Ferras, Supreme Court of Canada File No. 30211, Factum of the Respondent. 
otherwise, that the evidence is available for trial." ${ }^{93}$ In terms of impeaching the reliability of the evidence, the person sought could lead their own evidence or make arguments about the evidence in the ROC. Informed in this way, the judge could "engage in a limited weighing of evidence to determine whether there was a plausible case. ${ }^{94}$ However, the evidence was presumed reliable and the challenge could only be successful if the evidence was "so defective or appears so unreliable that the judge concludes it would be dangerous or unsafe to convict" 95 or (in the phrase that ultimately shaped the jurisprudence) the evidence could be shown to be "manifestly unreliable." ${ }^{96}$ Notably, the Court did not go as far as Professor La Forest might have preferred, as the presumption of reliability essentially meant automatic admissibility in the absence of challenge from the person sought; the American ROC in Ferras itself featured hearsay that came from unsavoury witnesses.

While early commentary hailed the Ferras framework as bringing muchneeded rigour to the committal decision, ${ }^{97}$ the Crown immediately went about narrowing the window of fundamental justice that Ferras had tried to open. It found success and a sympathetic ear with Justice Doherty in the case of United States of America $v$ Anderson. ${ }^{98}$ While conceding that Ferras had "turned a new jurisprudential page in the law of extradition," 99 Justice Doherty characterized the scrutiny of the requesting state's evidence as a "limited qualitative evaluation" that:

[D]oes not envision weighing competing inferences that may arise from the evidence. It does not contemplate that the extradition judge will decide whether a witness is credible or his or her evidence is reliable. Nor does it call upon the extradition judge to evaluate the relative strength of the case put forward by the requesting state. There is no power to deny extradition in cases that appear to the extradition judge to be weak or unlikely to succeed at trial. ${ }^{100}$

93 Ferras, supra note 48 at para 50.

94 Ibid at para 54. The "limited weighing" predominantly refers to testing the inferences sought to be established by circumstantial evidence pursuant to $R v$ Arcuri, 2001 SCC 54.

$95 \quad$ Ibid at para 40.

96 Ibid.

97 See Botting, “The Supreme Court 'Decodes' the Extradition Act”, supra note 85.

98 Anderson, supra note 51. See also United States v Thomlinson, 2007 ONCA 42.

99 Anderson, supra note 51 at para 26.

100 Ibid at para 28 [emphasis added]. 


\section{MANITOBA LAW JOURNAL}

Evidence, he wrote, could be rendered defective or unreliable "due to problems inherent in the evidence itself, problems that undermine the credibility or reliability of the source of the evidence, or a combination of those two factors," but it was only where the concerns with the evidence became "sufficiently powerful to justify the complete rejection of the evidence" that they were even "germane" to the sufficiency of evidence inquiry. ${ }^{101}$ The presumption of reliability could only be overcome where the person sought could demonstrate "fundamental inadequacies or frailties" in the requesting state's evidence." 102

Justice Doherty's dicta in Anderson were influential in subsequent case law. The other most influential appellate court in extradition matters, the British Columbia Court of Appeal, initially resisted the tone struck by Anderson ${ }^{103}$ but softened its approach over time. ${ }^{104}$ The coup de grace came from Justice Cromwell whose judgment in MM put an authoritative seal on the Anderson line of case law. Stating that he "largely agree[d]" with Justice Doherty's interpretation of Ferras, Justice Cromwell echoed the narrowing language from Anderson ${ }^{105}$ and further shrank any hope of meaningful evaluation of the requesting state's evidence:

\section{Ferras does not call upon the extradition judge to evaluate the relative strength of the case put forward by the requesting state. There is no power to deny extradition simply because the case appears to the extradition judge to be weak or unlikely to succeed at trial. ${ }^{106}$}

Justice Cromwell then went on to impose an additional procedural hurdle to a challenge of the requesting state's evidence. He noted that the task of the extradition judge was only one of limited weighing of the requesting state's evidence, and that any evidence sought to be used to challenge reliability had to be discretely relevant to this task. Accordingly, before even being allowed to lead the evidence, the person sought would have to make "an initial showing that the proposed evidence is realistically capable of satisfying the high standard that must be met in order to justify refusing committal on the basis of unreliability of the requesting state's

\footnotetext{
101 Ibid at para 30.

102 Ibid at para 31.

103 United States $v$ Graham, 2007 BCCA 345, in which Justice Donald referred to the Ontario Court of Appeal's approach as "reductionist."

104 See e.g. United States of America v SU, 2013 BCCA 483.

105 MM, supra note 9 at paras 71-72.

106 Ibid at para 71.
} 
evidence." ${ }^{107}$ Analogously to a Vukelich motion, ${ }^{108}$ this "initial showing" could include "summaries or will-say statements or similar offers of proof." 109

Justice Cromwell concluded by offering what he called "examples of evidence that may or may not meet the high threshold justifying a refusal of committal on the basis of unreliability of the evidence." His list of examples which "may not" meet the high threshold (because it was "irrelevant or not sufficiently cogent" ${ }^{110}$ ) included ${ }^{111}$ evidence that: goes to witness credibility; attempts to establish a competing inference of innocence; attempts to establish a defence; or presents a "different or exculpatory account of events." " Justice Cromwell offered no specific examples of evidence that "may" meet the high threshold, offering instead that even the types of evidence he had just referred to might establish unreliability in "certain, and likely fairly unusual cases" if it was "of virtually unimpeachable authenticity and reliability." However, such cases would be "very rare." 113

\section{Ferras and Fairness}

In my view, Ferras's promise of restoring a meaningful screening role for the committal judge has evaporated. This is because the Court's view in Ferras of the role played by the presumption that the ROC is reliable was too sanguine or even incautious. Practically speaking, rebutting the presumption of reliability is not only a difficult hill to scale but an impossible one. Individuals sought routinely challenge reliability on the basis of information known to them or that can be squeezed out of the ROC documents themselves - bearing in mind that these are tailored by the requesting states and the IAG and that disclosure is practically a non-starter - only to meet a ruling that questions regarding the reliability of the evidence should be handled by the trial court in the requesting state.

107 Ibid at para 77.

108 A hearing in which the court will decide whether it will even allow the accused to make a Charter motion. See $R v$ Cody, 2017 SCC 31 at para 38.

109 MM, supra note 9 at para 77. This too appears to have originated in Anderson, supra note 51 at paras 43-46, adopted from the earlier case of $R v$ Mach, [2006] OJ No 3204, 70 WCB (2d) 318 (Ont Sup Ct).

110 MM, supra note 9 at para 81 .

111 Ibid at paras 82-84.

$112 \quad$ Ibid at para 84.

$113 \quad$ Ibid at para 85. 


\section{MANITOBA LAW JOURNAL}

Between them, the Ontario Court of Appeal and the Supreme Court have essentially interpreted Ferras out of practical existence.

It is helpful to contextualize this argument with reference to what might inelegantly be referred to as the Crown's "win/loss record" in extradition cases generally, and at the committal stage specifically. Anecdotally speaking, it is well-known among defence lawyers that arrest of a client on an extradition warrant means they are usually facing a process that is practically a fait accompli, and that the best advice the lawyer can give is to immediately retain local counsel in the requesting state in hope of negotiating a plea deal in exchange for waiving the extradition process. ${ }^{114} \mathrm{~A}$ well-known "joke" about extradition is that there is only one question that needs answering: aisle or window seat? ${ }^{115}$ In light of Hassan Diab's wrongful extradition to France this "joke" seems in poor taste, yet it accurately captures the extent to which, at least in the perception of non-Crown people interested in extradition, the deck is stacked.

This anecdotal understanding is borne out, moreover, by data. In terms of the broader question of whether extradition efforts by the Crown result in extradition, any brief look at the extradition case law would indicate that the overwhelming majority of challenges to extradition are lost by the person sought and result in "success" for the Crown. ${ }^{116}$ This figure would not take into account those cases where extradition is not contested by the person sought, which would make the Crown's "success" rate higher still. In the wake of Hassan Diab's return from France, IAG disclosed statistics which indicated that individuals sought are in fact surrendered in $90 \%$ of cases. ${ }^{117}$

More to the point of this article, however, is that a look specifically at reported committal decisions shows that Justice Cromwell aptly described successful challenges to the requesting state's case as "very rare." As one

114 See Weinstein \& Dennison, supra note 33, c 4.

115 Roger Clark, "Clark: Results of inquiry into Hassan Diab's extradition must be made public now”, Ottawa Citizen (17 July 2019), online: <ottawacitizen.com/opinion/colum nists/clark-results-of-inquiry-into-hassan-diabs-extradition-must-be-made-public-now $>$ [p erma.cc/TGX2-VFTT].

116 Whether it is even appropriate to refer to a completed extradition as a "win" or "success" for the Crown is an interesting question, which is taken up in Section IV below.

117 Lisa Laventure \& David Cochrane, “Canada's high extradition rate spurs calls for reform”, CBC News (30 May 2018), online: <www.cbc.ca/news/politics/extraditionarrest-canada-diab-1.4683289> [perma.cc/Z9CQ-45HX]. 
reliable text notes, ${ }^{118}$ successful challenges at the committal hearing are rare, and successful appeals of committal orders are rarer still. Moreover, in 2017 I directed a study of 198 post-Ferras committal decisions reported between 2006 and 2017, which revealed only 16 successful challenges among all of the cases. ${ }^{119}$

It is important to acknowledge that these numbers represent a crude measure of a more nuanced situation. While this is an unpopular view among defence lawyers, it seems sensible to conclude that a strong plurality, if not a majority, of extradition requests are well-founded and rest on a reasonable evidential record. Moreover, if an extradition case is put forward by the IAG for a committal hearing, then this means that the ROC has been evaluated - in light of both the relevant treaty and the Act - and the Crown has a certain amount of confidence in the overall quality of the case. The IAG notes publicly that it is responsible for Canada's communications and dealings with its extradition partners, ${ }^{120}$ and it is reasonable to infer (and has been anecdotally indicated to me) that weaker or ill-founded requests are either screened out or sent back to the requesting state for repair. On this logic then, a simple request-to-committal ratio does not account for the legal strength of those cases that actually proceed through the process.

However, on the specific issue of the committal test, a look at the 16 successful cases from the above-noted survey is revealing. In a strong majority of them, committal was not refused because the requesting state's evidence (almost always in an ROC) was - in the language of Ferras "defective or unreliable," but because evidence was simply not present on one or more elements of the charged offence. For example, in Kamaldin the allegation was that the six persons sought had engaged in telemarketing

118 Weinstein \& Dennison, supra note 33.

119 United States of America v Kamaldin, 2016 QCCS 6228; United States of America v Toren, 2012 BCSC 1655; United States v Yu, 2011 ONSC 2777; Hungary (Republic) v Valde, 2011 ONSC 328; Hungary (Republic) v Pataki, 2010 ONSC 2663; United States v Gillingham, [2007] OJ No 4402, 75 WCB (2d) 438 (Ont Sup Ct); United States v Laird, 2010 ONSC 1553; Anderson $v$ United States, 2006 QCCS 4211; United States $v$ Cheema, 2007 BCCA 342; Pelchat c Canada, 2008 QCCA 74; DiRienzo c Canada, 2005CarswellQue 13334; United States of America v Viscomi, 2015 ONCA 484; United States of America v Aneja, 2012 ONSC 4062; United States of America v Robertson, 2012 BCSC 1800; United States $v$ Walker, 2011 BCCA 110; Seifert v Italy (Republic), 2007 BCCA 420 [Seifert CA]. In some cases, the challenges were only partly successful, and the individual was committed on other charges.

120 "About the International Assistance Group", supra note 38. 


\section{MANITOBA LAW JOURNAL}

fraud, but for one of the six, Iacino, the only evidence was that he had visited the site of the operation once and was there when arrests were executed; there were no fingerprints or any other evidence of his participation in the offences. In three other fraud cases (Valde, Pataki, and Gillingham), evidence of mens rea was missing from the requesting state's case as to some of the persons sought. In Pelchat, evidence of the actus reus of manufacturing a controlled substance was missing, as was evidence of aiding and abetting the production. In Di Rienzo, two of the five people sought were discharged because the evidence did not show proof of their knowledge of the conspiracies for which they were sought; a similar discharge resulted in Cheema. In Aneja, the person sought was committed on several charges relating to a fraud investigation but discharged on obstruction of justice because his impugned statements did not relate to the investigation itself, and there was therefore a gap in evidence on the actus reus of the offence. In Walker, there was so little information relating to an alleged eyewitness identification that the committal judge could not even determine sufficiency. ${ }^{121}$ In Seifert, the person sought was committed on a number of charges but discharged on one for which there was no evidence of causation and another for which there was no evidence of causation or identity. ${ }^{122}$

Some of the cases show a mixture of a lack of evidence and "defective and unreliable" evidence. In $Y u$, one of the persons sought, Chuck, was discharged because the evidence in the ROC purporting to implicate him in the charges was a mixture of mistaken identification, inconsistent inferences, bad translation, and baseless assertions by investigators. In Laird, the person sought was accused of having drugged and sexually assaulted the victim, but there was no evidence of how the victim had ingested the drug and the Crown's inferences were, at best, speculation. In Anderson, the judge struck summaries of Canadian-gathered wiretap evidence from the ROC because it had not been led in the hearing, as required under the Act, and,

121 It appears Walker was eventually extradited when a revised ROC was submitted. See United States $v$ Walker, 2011 BCCA 110.

122 Seifert $v$ Italy (Republic), 2003 BCSC 1317. Strictly speaking, this was a pre-Ferras ruling, insofar as the committal judge's decision came before Ferras was released. However, if anything, the committal judge applied an even more Crown-friendly test than Ferras (see paras 20-22). The Court of Appeal in Seifert CA, supra note 121 did a de novo committal assessment using Ferras but upheld these two discharges without comment. 
as a result, the case suffered from a total absence of proof regarding some of the persons sought. ${ }^{123}$

In all of these cases, the challenged evidence was fairly hopeless; even bearing in mind the challenges of dealing with authorities in requesting states and the development of evidentiary records, one wonders why the Crown went forward. In any event, Ferras promised that the person sought would have the opportunity to challenge weak evidence, but what the case law shows is this: all the law truly seems to provide is the much narrower opportunity, in cases where there really is no evidence, to point it out. Other reliability issues with the requesting state's evidence, no matter how grave, are simply left for the requesting state's trial courts to sort out. It also raises the possibility that after the constriction of Ferras between Anderson and MM, the window of fairness for the person sought is so narrow that we must be fearful that wrongful extraditions are happening.

This is not to say that our extradition process is itself wholly toxic; by analogy, we do not mistrust the entire criminal justice system because we know there are problems with wrongful convictions. However, in the latter space, the Supreme Court of Canada, appellate courts, and successive government inquiries have shaped the common law and pushed Parliamentary reform to deal with the problem. In the extradition space, the Crown-designed process is accepted, mostly uncritically, by the courts, and reform proposals do not attract interest.

If the examples cited above are not completely convincing on this point, there is no better support for this argument than the Diab case. The evidence in the French ROC was mostly geared toward identifying an individual known as "Panadriyu" as the bomber, and the case came down to a handwriting analysis report by a French expert which purported to link Diab's handwriting to samples of handwriting suspected to be that of Panadriyu. The reliability of the report was attacked by three defence experts, and among the committal judge's findings were that the report "ha[d] been shown to be based on some questionable methods and on an analysis that seems very problematic" 124 and was "susceptible to a great deal of criticism and attack;" 125 it was "convoluted, very confusing, [and] with

See United States of America v Fraser, 2017 BCCA 136; United States of America v Tahvili, 2008 BCCA 359.

124 Diab Sup Ct, supra note 20 at para 118.

125 Ibid at para 120. 


\section{MANitoba LaW JOURNAL}

conclusions that are suspect." ${ }^{126}$ However, relying on Anderson, the judge found that he had no choice but to order committal; despite these "major weaknesses," choosing between competing expert views was ultimately the task of the foreign trial court and, somehow, the presumption of reliability was not overcome. ${ }^{127}$ The Court of Appeal upheld the decision, noting that the expert evidence could only have been "manifestly unreliable" if it was "devoid of reliability and of utility to the fact finder."

With respect, it is difficult to imagine a case where evidence proffered by the requesting state was more "devoid of reliability and utility," and yet it was on the basis of this report that Hassan Diab was extradited to France to face a prosecutorial case that, as noted above, ultimately fell apart. This case therefore demonstrates two interlocking problems. First, if the "questionable," "problematic," "convoluted," "confusing," and "suspect" evidence in Diab was not manifestly unreliable, then arguably the test cannot actually be met. If there is any evidence, regardless of how poor or suspect, then the trial court in the requesting state is the appropriate place deal with its problems. Canada's courts are truly applying the old Shephard test and just calling it by another name.

Second, if one accepts that the test has been correctly stated and is being correctly applied in law (in cases like Diab and MM), then it is acceptable for Canadians to be extradited on the basis of evidence that is "questionable," "problematic," "convoluted," "confusing," and "suspect" and by way of a process in which it is essentially impossible meaningfully to challenge that evidence and bring out its weakness. Surely, such an unfair process is not in line with "fundamental justice" such that it is acceptable to Canadians. In Ferras the Supreme Court promised a "meaningful judicial determination," ${ }^{129}$ but individuals like Hassan Diab did not receive and are not receiving it. Compliance with the principles of fundamental justice under section 7 of the Charter demands better. Since, as Justice Cromwell wrote in $\mathrm{MM}$, "[t]here is no power to deny extradition simply because the case appears to the extradition judge to be weak or unlikely to succeed at trial," ${ }^{130}$ then Diab's case shows that such a power needs to be created.

\footnotetext{
$126 \quad$ Ibid at para 121.

127 Ibid at paras 122-23.

128 Diab CA, supra note 22 at para 126.

129 Ferras, supra note 48 at para 26.

130 MM, supra note 9 at para 71 .
} 


\section{Efficiency and Expeditiousness}

This problem is compounded by the insistence in the extradition jurisprudence that extradition is intended to be "expeditious and efficient", even summary in nature - which infects not only what scrutiny is to be given to the requesting state's case but, generally, how fair the committal hearing must be in order to be Charter-compliant. The most currently authoritative version of this can be found in MM. Charged with abducting her children, Messina had argued that the defence of necessity would be available to her if the conduct had occurred in Canada, as she had been helping her children to flee their abusive father, and thus double criminality could not be made out. For the majority, Justice Cromwell took the opportunity to reinforce what he referred to as "long-settled principles about the extradition process," ${ }^{131}$ which centred around the theme that "expeditiousness and efficiency" mean that "an extradition hearing is not a trial and it should never be permitted to become one." 132 This weighed against the argument that defences could even be considered at the committal stage since committal had fundamentally the same limited function as a preliminary inquiry, which is to determine whether there is any evidence that justified committal for trial. Defences, Justice Cromwell wrote, "have never formed part of the test for committal to trial in the preliminary inquiry context," and to allow consideration of them "would fundamentally change the nature of the extradition hearing, making it more akin to a trial." 133 Ferras, he conceded, had expanded the scope of the committal judge's powers somewhat due to its requirement that the judge be permitted to engage in a limited weighing of the requesting state's evidence. However, this did not expand the issues to which the judge was confined to considering:

Ferras's insistence on a meaningful judicial determination by the extradition judge speaks only to the rigour that an extradition judge must bring to the assessment of the evidence. Ferras did not - indeed could not - change by judicial decree the statutory requirement that the requesting state has only to show that the record would justify committal for trial in Canada. The committal for trial process has never been concerned with possible defences on which the accused bears an

$131 \quad$ Ibid at para 41.

132 Ibid at para 64.

133 Ibid at para 86. 


\section{MANITOBA LAW JOURNAL}

evidential or persuasive burden and Ferras provides no support for any fundamental change to this statutory test for committal. ${ }^{134}$

A three-judge dissent led by Justice Abella argued that any meaningful application of the concept of "double criminality" meant that the committal judge must take into account clear evidence showing that the person sought has a defence available. While Justice Cromwell responded - correctly in my view - that this did damage to the statutory language that clearly confined the committal process and any defence-side evidence to the firmness of the requesting state's evidence, ${ }^{135}$ Justice Abella's reasons were grounded in Ferras's fundamental holding that the committal process is only Charter-compliant if there is "meaningful judicial assessment" of the evidence. She wrote:

A meaningful judicial determination of whether the double criminality requirement is met should not be sacrificed on the altar of potential concerns of expediency, comity and cost. These concerns are adequately addressed in the existing extradition process and not undermined by consideration of the viability of a [necessity] defence. In any event, they must be counterbalanced against the need for a meaningful judicial assessment of the case based on the evidence and the law so that the liberty interests of the person sought for extradition are fully respected and protected. ${ }^{136}$

The dissenting argument has much to commend. It is reasonable to say that extradition should not become a trial, but if it is to comport with basic fairness, neither does it need to be the furthest thing from a trial. Allowing consideration of defences might depart from the preliminary inquiry structure upon which committal is based, but as the Court itself pointed out in Ferras, the Act does not demand slavish adherence to that structure. ${ }^{137}$ If compliance with the principles of fundamental justice could justify expanding the scope of evidentiary consideration as a "meaningful judicial process," it could safely justify including consideration of defences as well. It is worth remembering that preliminary inquiries (a fully criminal procedure) and extradition (a process Crown personnel insist on referring to as "civil") may have technically similar goals but produce different results. A person who is committed for trial after a preliminary inquiry is going to face a trial within the Canadian criminal justice system, in which we are confident. A person extradited faces consequences which are "more

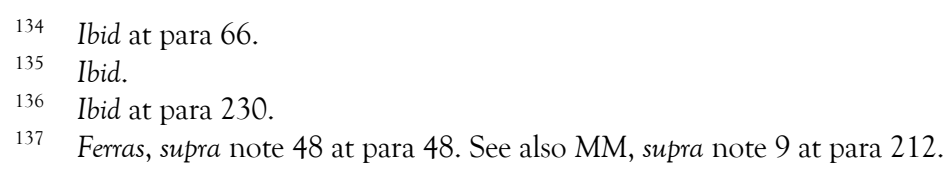


onerous." ${ }^{138}$ Like Hassan Diab, this person will be sent to a foreign state where they may never have been ${ }^{139}$ and where they may not speak the local language; they may face a foreign justice system that has significant problems, such as prosecutors who wish to rely on secret intelligence as evidence or have drawn conclusions on the basis of incompetently-gathered evidence. ${ }^{140}$ Like Michele Messina, a defence that would be available to them under Canadian law may not even be available in the requesting state, in a case engaging the kind of gendered violence that Canada has committed both domestically and internationally to combat. ${ }^{141}$ "Fundamental justice" by way of a "meaningful judicial process" may require a broader scope of inquiry.

The six to three margin in MM shows, however, that challenging the current Crown-driven view of the extradition process - which is supported by decades of extradition jurisprudence - is an uphill battle. The debate in MM around whether defences can be considered in the committal hearing is emblematic of the fact that the current process, underpinned by overwhelming judicial acceptance of the Crown's policy agenda, has essentially fetishized the mantras of "extradition cannot be a trial" and "extradition must be efficient." Even if one accepts that the current system is defensible in terms of complying with the scheme Parliament has laid out in the 1999 Extradition Act, it is worth asking the hard but basic democratic question: now that we have seen it in action for over 20 years, is this kind of process actually what Canadians want? It may be, as Justice Cromwell wrote in $\mathrm{MM}$, that "[b]asic fairness to the person sought does not require that the extradition process have all of the safeguards of a trial" ${ }^{142}$ but

La Forest, supra note 7 at para 132.

It is increasingly common for some states, particularly the U.S., to assert "extended territorial jurisdiction" and request extradition of individuals whose alleged criminal conduct touched U.S. territory in some way but who never left Canada. See e.g. Sheck $v$ Canada (Minister of Justice), 2019 BCCA 364. There is nothing disturbing about this in principle, as Canada asserts the same form of jurisdiction. However, in practice, the U.S. has requested jurisdiction on the basis of very broad assertions of extended territoriality. See e.g. United States v Meng, 2020 BCSC 785.

In Diab, part of the French investigation consisted of two French handwriting "experts" who found that an early sample of Diab's handwriting was a match for handwriting suspected to be that of the bomber. It was later revealed that the sample was actually the handwriting of Diab's then-wife. See Segal Report, supra note 16 at 37.

141 MM, supra note 9 at paras 217-24 per Justice Abella.

$142 \quad$ Ibid at para 53. 


\section{MANITOBA LAW JOURNAL}

safeguards it should have. In my view, there are aspects of basic fairness missing from the extradition machinery which could potentially be remedied by changes that maintain efficiency and keep extradition from devolving into some kind of preliminary trial while, at the same time, do a more robust, effective, and Charter-compliant job of protecting the rights of the individual sought. If changes would mean going beyond "settled principles" of extradition law, then it is time to unsettle those principles.

\section{Reforming the Committal Phase: How to Right the Ship?}

This article will not provide a re-write of the Extradition Act's provisions dealing with committal, though this should be done and only after scrutiny by a Parliamentary committee with substantial (and heretofore sorelylacking) public input. A judicial inquiry into the Hassan Diab case, as was proposed by Diab and his many supporters, would also serve to highlight problems and generate solutions. However, a few proposals can be offered.

The primary focus of reform efforts should be on un-neutering the "meaningful judicial process" that Ferras framed as a principle of fundamental justice by making the system fairer to the person sought. Extradition can and probably should, in some sense, be expeditious, and it makes sense that committal should not be a preliminary attempt to litigate the anticipated criminal trial in the requesting state. However, "expeditious" does not mean "summary," and the current formulation of the committal process is just that. It requires some expansion to be fair.

The Halifax Colloquium ${ }^{143}$ has proposed a number of interlocking reforms that would be worth exploring. An explicit but modified invocation of the presumption of innocence on the process would provide balance: "explicit" in that it should be inserted into the Act, but "modified" in that it would not bring with it an obligation on the Crown to offer proof beyond a reasonable doubt. The idea would be to send the signal to the committal judge that an adjudication of guilt or innocence is sought by the Crown at the end of the process, and that the requesting state's case should be appropriately scrutinized and some equality of arms between the Crown and defence actively sought.

One way to achieve the latter goal would be to remove the presumption of reliability from the ROC approach and require the Crown to prove reliability on a balance of probabilities. Even if the threshold to be met could be shaped by taking into account the peculiarities of the extradition 
context - and perhaps be slightly more modest for the Crown - this change would sweep away the current dysfunction around the "manifestly unreliable" standard. Making this exercise meaningful, in turn, could be accomplished by moving somewhat back in the direction of the old prima facie case requirement - to wit, key witness evidence could be offered in the form of affidavits and the affiants made available for cross-examination. "The purpose of the cross-examination would be to explore whether the witness is fundamentally reliable and not for exploring credibility simpliciter. This is especially important if the witness has taken a plea deal"144 or is otherwise what Canadian law would label a Vetrovec witness.

To the extent that this proposal would appear regressive, unwieldy, or undesirable, there are $21^{\text {st }}$ century solutions that would buff off the rough edges. Recalling that an explicit rationale for abandoning the prima facie case approach in the new Act was that some foreign legal systems do not have the capacity to generate what we recognize as sworn evidence, Canada could agree with the requesting state that a government official in the foreign state could take the witness's affidavit in a special but brief procedure in which Canadian law would apply. If this seems overly complex, it is not; Canada already has such arrangements in place in some of its mutual legal assistance treaties (MLATs), ${ }^{145}$ and provisions could be inserted into existing MLATs or even into the extradition treaties themselves. So far as cross-examination goes, in post-COVID 19 times, video-conferencing is an eminently practical solution, and one which is, in fact, already used to allow testimony from foreign witnesses in domestic criminal trials. ${ }^{146}$

Despite Murray Segal's recommendation that ROCs be more "streamlined and economical" - i.e., contain even less than they currently do - his scrutiny of the Diab case led him to recommend that in any case where the requesting state intends to rely on expert reports, the reports must

144 Ibid.

145 Notably, the Canada-US treaty, supra note 34. See Rv Dorsay, 2006 BCCA 117, 42 CR (6th) 155, leave to appeal to SCC refused, [2006] SCCA No 374.

146 See e.g. $R v S$ (2018), 2018 ONCA 962. The Crown's evidence in on one war crimes case was led entirely via video. See Currie \& Rikhof, supra note 29 at 314. Crossexamination on affidavits via video is already happening in civil cases. See e.g. Sandhu v Siri Guru Nanak Sikh Gurdwara of Alberta, 2020 ABQB 359. Wagner CJC recently suggested its use for domestic trials. See Olivia Stefanovich, "Supreme Court chief justice suggests Criminal Code changes to cut into court backlogs", CBC News (13 June 2020), online: <www.cbc.ca/news/politics/stefanovich-chief-justice-reopening-proposal s-1.5604773? cmp=rss> [perma.cc/9TZQ-FL8Z]. 


\section{MANITOBA LAW JOURNAL}

be led in evidence and not simply summarized in the ROC. ${ }^{147}$ He invoked in justification the findings of the Goudge Inquiry, among others, that untrustworthy expert opinion has played a role in wrongful convictions and is worthy of special scrutiny and caution. ${ }^{148}$ In light of Diab, where unreliable expert evidence caused a wrongful extradition, this makes good sense. While Segal stopped short of recommending that the reports be held admissible in accordance with the White Burgess test in Canadian evidence law (an argument that the committal court and the Court of Appeal rejected in Diab), this too would seem logical. Moreover, the IAG should make it clear to treaty partners that this kind of evidence, in particular, must mandatorily be disclosed for extradition purposes if it is going to be led at trial; this could be backed by a treaty obligation, if necessary.

The Halifax Colloquium also proposed that the committal judge should admit and consider defence-side evidence on any excuse, defence, or justification that would be available to a person sought under either Canadian law or the law of the requested state. A robustly-proven defence might produce a discharge. In light of MM firmly slamming the door shut on this point, it is likely that it would need to be accomplished through amending the Act. However, there is a model to start with, as federal immigration proceedings considering criminal inadmissibility explicitly consider available defences and immunities. ${ }^{149}$

Even in my mind, this is something that would have to be carefully calibrated given the potential for time-wasting and disruption it might cause. It should probably be limited to affirmative defences rather than simple attacks on the elements of the offence (e.g., "I did not intend to do it" as an attack on mens rea). It might be that the evidence would need to have an "air of reality" even to be considered, much as is required in criminal cases. ${ }^{150}$ Otherwise, it is too easy to imagine defences based on bare assertions (e.g., "she attacked me, it was self-defence"). A modified air of reality test might be applied, such that the judge would have to find that a reasonable jury could find the defence to be made out on a balance of probabilities (rather than just raising a reasonable doubt), even for those defences that do not require this standard of proof under Canadian law.

\footnotetext{
147 Segal Report, supra note 16 at 88.

148 Ibid at 90.

149 Bellevue v Canada (Minister of Public Safety and Emergency Preparedness), 2020 FC 560 at paras 33-34.

$150 \quad R v$ Cinous, 2002 SCC 29.
} 
At its most conservative, perhaps this change could apply only in cases like $M M$ itself where the main problem was that the evidence disclosed a defence that would have been available to Messina in Canada but was not available to her in the requesting state. As the dissent in MM argued powerfully, denying a challenge in this situation flies in the face of any meaningful version of double criminality, if not the technical manner in which it currently operates. The majority justified precluding this issue from consideration by the committal judge by noting that it is within the purview of the Minister to consider it when making the surrender decision. ${ }^{151}$ Whether the Act appropriately balances the tasks in the extradition process between the judicial and Ministerial phases will be the subject of a future article. Suffice it to say that the issue of availability of defences is, in my view, a predominantly legal question that belongs in the hands of a judge who is directed by discrete statutory language formulated by Parliament and not in those of a Minister of the Crown who is making an explicitly "political" decision that enjoys the most deferential standard of review known to Canadian administrative law. ${ }^{152}$

This point of view also reflects the reality that, so far as any meaningful public information could show, there are very few cases in which the Minister has actually refused surrender. ${ }^{153}$ Stays of surrender, even in meritorious cases, mostly only occur where the courts can be convinced to order them, and this too is rare. ${ }^{154}$ The tragic result of the MM case gives some measure of the reality around this and of the troubling enthusiasm for extradition on the Crown side, to which this paper now turns.

\section{THE ROLE OF THE CROWN}

\section{A. Crown "Culture"}

As noted in Section III.C above, Justice Canada is responsible for conducting extradition proceedings on behalf of the Crown, both through

151

152

153

MM, supra note 9 at paras 116-18.

Lake, supra note 55.

One experienced extradition practitioner described them to me as "scarce as hen's teeth." In my own decades of studying and working on extradition cases, I have only seen one and heard of a few others.

In India $v$ Badesha, 2018 BCCA 470 [Badesha] the Court of Appeal refused to order a stay even after finding an abuse of process by the Canadian Crown. 


\section{MANitoba LaW JOURNAL}

the IAG and litigation counsel. In this section, I will argue that part of the problem with how extradition proceedings generally, and the committal phrase in particular, are conducted is in the way that the Crown and the law conceive the Crown's role and in how that role is executed.

The Crown side of extradition is notoriously murky, a fact remarked upon even by the Segal Report ${ }^{155}$ which was otherwise sympathetic to the Crown's role in the Diab case. However, the same Report does shed some light on how the Crown actually operates through the committal and surrender process. ${ }^{156}$ In Diab, an IAG lawyer interacted closely with the investigating judge in France, ${ }^{157}$ conducting and co-ordinating communications between French and Canadian authorities. In particular, this lawyer worked closely with the Canadian legal team that was actually litigating the committal proceedings, assisting with evidentiary and other requests. The litigation team itself was staffed by IAG lawyers and staff. ${ }^{158}$ After committal, IAG counsel prepared the usual report for the Minister, facilitated defence submissions on surrender, provided legal advice to the Minister, and drafted his surrender decision. IAG counsel also litigated the appeal of the committal decision and the judicial review of the surrender decision.

The Crown side, then, is essentially a unit, populated by lawyers and support staff among whom there is some differentiation of roles, but all of whom are working toward the same goal. Accurately articulating what that goal is, however, is key to understanding the true nature of the process. To frame it provocatively, is the goal "producing a fair result in an extradition proceeding," or is it "producing extradition, at whatever cost?"

Describing the Crown's role accurately, in terms of how it currently exists, will be helpful to ground suggestions about what it should be and how it should be structured. A key point is that the Crown differentiates its

155 Segal Report, supra note 16 at 106-08.

156 The IAG, as noted earlier, receives and evaluates incoming extradition requests, causes the ATP to be issued, facilitates arrest of the person sought, and so on. See Weinstein \& Dennison, supra note 33, c 2 .

157 Unusually in this case, the IAG lawyer, Jacques Lemire, was actually posted to France to play this role for Canada-France extraditions due to the historic connections between these states. However, IAG staff play this role from the Ottawa office as well.

158 Again, this was slightly unusual but had to do with the fact that the proceedings were being conducted in Ottawa where the IAG office is located and that the case involved many materials in French and were more easily accessible by the fluently bilingual IAG staff. 
role in extradition proceedings from the role of Crown prosecutors and specifically does not feel bound by prosecutors' enhanced obligation to achieve fairness in proceedings and results. The Segal Report, which was based in part on Segal's interviews with IAG personnel, explains this cogently. A Crown prosecutor, in line with traditional authority, ${ }^{159}$ is not acting as counsel for any particular party but is instead "a quasi-Minister of Justice" 160 simply concerned with producing a just result and eschewing any notion of "winning" or "losing." In extradition proceedings, by contrast, the Crown is acting as counsel for a party (specifically, the requesting state) and is indeed seeking a "win" for its client through "a more purely adversarial role":

Before a trial in Canada, Crowns must consider whether there is a reasonable prospect of conviction. They also have an obligation to evaluate the strength of their case at all stages of the proceedings. These types of considerations are not relevant to counsel for the Attorney General in extradition proceedings. These government lawyers are not charged with looking into the future and asking whether, down the line, there will be problems with the case or whether there is a reasonable prospect that the evidence available is capable of convincing a jury beyond a reasonable doubt. Instead, the objective of counsel for the Attorney General at the judicial phase is modest: can they establish a prima facie case against the person sought? There is good reason for this more circumscribed role. Counsel for the Attorney General in extradition proceedings are not building a case for trial. They are not responsible for and may not be knowledgeable about the trial procedures available in the requesting state; and, more to the point, they do not know what evidence will ultimately be available for trial in that country. ${ }^{161}$

On this view, then, the Crown's job in extradition proceedings is to facilitate extradition. The Crown is fighting the person sought, on behalf of its client. The committal phase - indeed, the entire process - is adversarial and, beyond complying with ethics and procedure, no holds should be barred. Protections for the person sought can be sought by that person; the system is designed to be fair and Charter-compliant, and of course the individual will be represented by able counsel. The nature of the process, as explained in the excerpt above, drives the scope of the Crown's function.

Or so goes the narrative. Putting aside the argument in section III above (that the system is neither fairly designed nor Charter-compliant), and (2000), 149 CCC (3d) 193, 48 WCB (2d) 200 (ONCA).

160 Segal Report, supra note 16 at 81.

161 Ibid at 82. 


\section{MANitoba LaW JOURnal}

putting aside the pressing issue of access to justice in this country and whether individuals sought will even have meaningful access to counsel, ${ }^{162}$ I would argue that this is a cultural standpoint and not a legal one. This is not to say that it has no grounding in law - quite the contrary, in fact. This view of the Crown's role is certainly facilitated by the structure of the Act and the Crown-side policy arguments that have found favour in the jurisprudence. ${ }^{163}$ However, this construction of the role has been chosen by the Crown for itself. It is by no means an inevitable version of what the role of the Crown might be in a reasonable, fair, and Charter-compliant extradition process.

To say that the Crown's role is the simple one of demonstrating a sufficient case for committal, and that it is divorced from any knowledge of or responsibility for the trial in the requesting state, is simply a policy choice. To repeat the mantra of "extradition is not a trial, the trial takes place in the requesting state" is also a choice, and this particular choice artificially dissociates Canada from the result of the extradition process: the ultimate fate of the person sought. To say "extradition is not a criminal law process" ignores the fact that the goal of the process is to have the person sought wrung through the criminal justice system of a foreign state ${ }^{164}$ and either into its prisons or some other hardship. Hassan Diab and Michele Messina learned this lesson, as they say, the hard way, and no sensible person would say that Canada was not instrumental to what happened to each of them.

Putting the interests of comity at the front does, of course, drive an argument that this dissociation is necessary or inevitable; we must respect the processes of our foreign partners and so on. However, the best counterargument can be found in the part of the extradition process where comity matters most, which is the surrender phase. At that point, the

162 Notably, Hassan Diab was represented by one of the most prestigious criminal defence lawyers in Canada, Don Bayne, who was acting pro bono. Not all individuals sought are so fortunate; some extradition defences are conducted by over-stretched legal aid counsel or local defence lawyers who might see only one extradition case in their career. In his writing, Gary Botting has made the point that the Supreme Court's post-Charter extradition jurisprudence reflects the many leading decisions written by Justice Gerard La Forest, which carried a very pro-extradition and pro-comity flavour. Indeed, the first edition of the La Forest textbook, which was written by Justice La Forest, was written as an extradition manual for Department of Justice lawyers (See Botting, Extradition Between Canada and the United States, supra note 92 at 22-27).

164 Of course, it should be acknowledged that in some cases the "foreign state" will be the state of the person's nationality, though nothing depends on that point nor does it undermine the argument I am making here. 
Minister is constrained by the Charter not to surrender the individual to the foreign state in circumstances where their fate, as a result of being surrendered, would not be consistent with the principles of fundamental justice. ${ }^{165}$ Comity is balanced against that vital, constitutional interest. That is to say, what will happen to the individual as a result of actually being surrendered is a driver of the law in the surrender phase. There is no principled reason that, properly tailored, this legal interest cannot be taken into account at the committal stage. There is no reason that committal needs to be almost ${ }^{166}$ completely unconcerned with the criminal process and trial that awaits the person sought. There is, moreover, no reason that Crown personnel cannot act as "ministers of justice" in committal proceedings.

To reach this conclusion, however, would take not only legislative amendment but a shift in the culture among Crown personnel who conduct extradition cases. Again, it is sometimes necessary to resort to anecdotal evidence to make certain points, both because there is so little inquiry and commentary on extradition in Canada and because Justice Canada and the IAG in particular are so opaque and secretive. ${ }^{167}$ Anecdotally speaking, then, it is well-known in Canadian circles that the Crown is ferocious and extremely adversarial in advancing the interests of its "clients" in extradition matters. Given the view of its role as expressed in the Segal Report, this would be unsurprising, and, of course, litigation is hardly a "tea party" as the old saying goes; one could expect, and even hope, for some tough lawyering given the important goals that extradition fulfills.

That said, this adversarial stance sometimes appears excessive. In the case of Abdullah Khadr, for example, disclosure during the committal hearing revealed that the requesting state, the U.S., had engaged in what the committal judge termed "gross misconduct," not least by putting a bounty on the head of the person sought, facilitating his mistreatment by Pakistani security forces, and breaching Canada's right of access to its citizen

165 Canada v Schmidt, [1987] 1 SCR 500 at 522, 39 DLR (4th) 18; Burns, supra note 57; MM, supra note 9.

166 I say "almost" because the committal judge does have a narrow Charter-based jurisdiction to maintain the fairness of the hearing itself. This jurisdiction, in very rare circumstances, can produce a stay of proceedings based on the conduct of the requesting state. See Weinstein \& Dennison, supra note 33, c 9.

167 Even the Segal Report makes this point. See Segal Report, supra note 16 at 107. 


\section{MANITOBA LAW JOURNAL}

under international law. ${ }^{168}$ It seemed clear that in requesting Khadr after all of this, the US was clearly abusing the process of Canada's courts, yet the Crown pressed for extradition. When the committal judge stayed the proceeding because it was an abuse of process, the Crown appealed to the Ontario Court of Appeal where Justice Sharpe denounced both the extradition request and some of the Crown's legal arguments in no uncertain terms, noting that to allow extradition in such circumstances would undermine the rule of law. ${ }^{169}$ The Crown's response? A leave application to the Supreme Court of Canada which was denied. ${ }^{170}$

The pressing question, in my view, is why the Crown "went to the wall" (to again use a colloquial phrase) on this case. The basis of the appeal seemed to be the issue of whether the two levels of court were somehow misapplying the test for abuse of process, though the arguments were not convincing. The leave application itself was a surprise; surely when one is handed such a resounding defeat by two levels of court, the best course would be to give up - not to press on with an extradition case so desperately tainted by the unlawful and shocking actions of the very state requesting extradition. Surely the people of Canada would want its government to stop such a case in its tracks after these court findings, at the very least so as not to throw good taxpayer dollars (lawyer time, resources) after bad.

Yet there are cases that make it appear that the Crown is sometimes willing to pursue extradition at all costs. It is worth recalling that the landmark Supreme Court of Canada case on abuse of process at the committal phase, Cobb, ${ }^{171}$ came about because the Crown insisted on pressing forward with the extradition of a man who had been threatened by both the prosecutor and a presiding judge in the requesting state. In a recent and prominent British Columbia case, the IAG was so eager to keep two individuals from exercising any more procedural rights that it engaged in what the Court of Appeal called "subterfuge" in an attempt to rush them out of the country - which the Court held was an abuse of process that had "a very serious adverse impact on the integrity of the justice system." 172

\footnotetext{
168 United States $v$ Khadr, 2010 ONSC 4338.

$169 R v$ Cox, 2011 ONCA 58.

170 United States $v$ Khadr, 2011 ONCA 358, leave to appeal to SCC refused, 34357 (29 July 2011).

171 United States $v$ Cobb, 2001 SCC 19.

172 Badesha, supra note 156 at para 77.
} 


\section{B. Diab: "Lessons Learned"?}

The Diab case, one where more detail is known than most, is highly illustrative of the point I am making here. The Segal Report is replete with disturbing details, among them:

- At the bail stage, the Crown did not provide an English translation of the French ROC materials and had to be ordered to do so, even though Diab was not fluent in French. It also opposed even the very restrictive bail that was granted and unsuccessfully challenged this at the Court of Appeal; ${ }^{173}$

- For some reason the IAG initially took the position that translation of the ROC materials was not its responsibility (though later this stance was "properly abandoned"); ${ }^{174}$

- Prior to the committal hearing proper, Diab's counsel indicated that he would lead expert evidence that would destroy the foundation of the French handwriting reports that formed part of the ROC. It eventually emerged that the reports had been partly based on handwriting that was not Diab's, but the experts nonetheless concluded that it matched the bomber's prints. To deal with this development, the advisory counsel and litigation counsel worked together to warn the French investigating judge that this would undermine the case and request that he obtain new handwriting analyses which could be used. In the meantime, litigation counsel continued to argue that the flawed handwriting analyses were sufficiently reliable to ground committal but later changed tack and submitted the new handwriting analyses when they arrived; ${ }^{175}$

- At one point, France realized that they had a sample of what were thought to be the bomber's prints and requested that IAG send Diab's fingerprints so that they could be compared. The Crown considered obtaining Diab's prints surreptitiously but concluded that his counsel would probably challenge this in

Segal Report, supra note 16 at $40-41$.

Ibid at 43.

Ibid at 55-56. This particular stratagem raised concerns the ethical soundness of Mr. Lefrancois's conduct, which I will not take up here but which Segal deals with at 95103. 


\section{MANITOBA LAW JOURNAL}

court. Instead, the Crown arranged for France to send copies of the prints to Canada for comparison with those found in Diab's arrest record. Of the six prints found in France, four of them were conclusively not Diab's, and two were held to be inconclusive. Despite the obviously exculpatory nature of this evidence, IAG counsel decided it was "neither inculpatory nor exculpatory," and while they sent the results to France, they did not disclose this to Diab on the basis that (1) the prints did not form part of the French case and (2) they did not want to take a chance of undermining the very restrictive approach taken to disclosure in the extradition case law; ${ }^{176}$

- It was clear that the ROC contained unsourced intelligence, the unreliability and dangers of which have long been known (particularly to those who work in inter-state criminal cooperation). ${ }^{177}$ The Crown unsuccessfully opposed Diab being permitted to lead evidence on this point, and it was only after Professor Kent Roach had testified about it and final arguments were about to begin that they withdrew reliance on the unsourced intelligence. ${ }^{178}$

Hassan Diab, it needs to be recalled, was wrongfully extradited. There is simply no other sensible conclusion. As regards the role of the Crown, the Segal Report is interesting because it raises two contradictory conclusions. The first is the conclusion reached by the report itself: in conducting the case, the Crown complied with all relevant legal and ethical norms and principles. This was certainly the view of the Crown officials to whom Segal spoke in preparing the Report; an internal "Lessons Learned" exercise ordered by the Minister revealed that IAG personnel found that "the current Canadian extradition system is fair and working well," and, if anything, it needed to be made more efficient. ${ }^{179}$ Specific to Diab, the only

Ibid at 10, 54. It is worth noting that the later French decision to discharge Diab held this very fingerprint evidence was "an essential element" of why the case against him was hopeless.

Kent Roach, "The Eroding Distinction Between Intelligence and Evidence in Terrorism Investigations" in Nicola McGarrity, Andrew Lynch \& George Williams, eds, CounterTerrorism and Beyond (New York: Routledge, 2010) 48.

Segal Report, supra note 16 at 60.

Ibid at 74 . 
problem with his case was that it was unduly protracted, and it was still entirely proper that he was extradited to France. ${ }^{180}$

Though perhaps undermined slightly by the fact that Segal consulted predominantly Crown sources in putting the report together, ${ }^{181}$ this conclusion is nonetheless technically defensible - based on the way the committal phase is structured and the Crown's view of their own function, everything is working as it is supposed to. Importantly, Segal's terms of reference excluded any consideration of the Extradition Act itself or any consideration of how things should be. His result, however, underpins the second conclusion: if the Hassan Diab case can be held up as a model of how extradition is supposed to work, then Canadians require a serious inquiry into "how things should be." This case featured Crown officials actively collaborating with a foreign state to shore up a case that was weak from the start, litigating with needless aggression against a Canadian citizen, withholding exculpatory evidence, and reaching the conclusion that a wrongful extradition was the correct result. All of this, of course, is in the context of a government department that dominates all of the decisionmaking, subject to the modest judicial role. Specifically, it assists the requesting state, litigates on its behalf, makes the decision on whether to extradite, and fights off appeals and judicial reviews. It seems to me beyond question that if this is the state of the law then Canadians need to consider whether this is desirable or whether the system needs to be reformed.

\section{Potential Changes}

As noted above, this paper can only suggest directions and a few potential fixes for the problems besetting the Crown's role in extradition since what is required is a full-scale judicial inquiry, sustained Parliamentary attention, or preferably both. That said, a few points offer themselves as obvious contenders for consideration.

The first is the issue of exculpatory evidence in the hands of the authorities. As noted earlier, outside the narrow scope of a Charter motion or the highly-circumscribed process around the sufficiency of the requesting state's case, the Crown has minimal duties of disclosure and the requesting

$180 \quad$ Ibid at 77.

181 And, to a limited extent, French sources of information. Segal notes that Dr. Diab and his counsel were invited to participate and declined. 


\section{MANITOBA LAW JOURNAL}

state is practically immune. ${ }^{182}$ While it would be useful to explore disclosure in detail, I would offer, at a minimum, that exculpatory evidence in the hands of the Crown should be disclosed to the person sought, full stop. Recognizing that there is no such obligation in the current law, even the Segal Report recommends that such disclosure could be made, where the evidence is high-quality, "as a courtesy or discretionary call made in the circumstances of the particular case." 183 The Halifax Colloquium expressed the view this disclosure should be mandatory rather than discretionary, and regardless of whether the evidence was independently gathered by Canadian officials or disclosed to them. Also, whether the evidence is "exculpatory" or not should be assessed in compliance with the Stinchcombe criteria that bind the Crown in criminal cases. This would avoid the kind of mischief that occurred in Diab, where the Crown decided that fingerprints predominantly excluding the person sought were somehow "neither inculpatory nor exculpatory."

The Segal Report also spoke to the inter-mingling of roles among the Crown personnel, noting that most typically the litigation is done by a federal Crown in the relevant province, instructed by IAG counsel who also acts as a go-between with the requesting state. IAG personnel would also "advise" the Minister, draft the Minister's decision, and then either conduct or instruct on appeals of committal and judicial reviews of surrender. Segal acknowledged that this might raise the appearance of conflicts of interest, particularly the direct contact between litigation counsel and the requesting state, which he viewed as generally inadvisable. ${ }^{184}$ Expressing his conviction that all involved "already act in a manner that ensures the requisite independence at each stage of the extradition proceedings," he nonetheless felt that a "formal" separation of roles "would increase transparency and help to ensure the appearance of independence." 185

The Halifax Colloquium essentially takes Segal's latter recommendation as a starting point. There must certainly be litigation counsel who conduct adversarial litigation in extradition, and one would really not expect anything different. However, there is something wrong with a structure where the entire governmental litigation, advisory, and decision-making machinery are all arrayed against the person sought and

\footnotetext{
182 Weinstein \& Dennison, supra note 33, c 8.

183 Segal Report, supra note 16 at 102.

184 Ibid at 84 .

185 Ibid at 85 .
} 
uniformly driven by the imperative to extradite -especially in a legal process that, as the Supreme Court reminds us in MM, is supposed to facilitate comity and protect the rights of the person sought equally. ${ }^{186} \mathrm{~A}$ foreign state is simply not an ordinary client. One way to think about it is to consider the Attorney General of Canada as representing the requesting state, so litigation counsel would act in this capacity; ${ }^{187}$ the Minister of Justice (despite being the Attorney General's alter ego in the constitutional sense) would play the separate and less adversarial role. Accordingly, separation could be imposed between Attorney General lawyers who litigate on the requesting states' behalf and the Minister's advisory counsel who facilitate communication with those states. The advisory counsel, in particular, should be oriented to act in the traditional Crown prosecutor mould of trying to achieve a just and fair result, rather than simply a "win."

All of this activity, moreover, should be separate from IAG's other function of advising the Minister on whether surrender should be ordered. These lawyers should not be, as the old saying goes, "in each other's pockets." To underscore that fair treatment is just as important as comity, the Halifax Colloquium recommended that like other federal agencies such as the Immigration and Refugee Board, the IAG should adopt an explicit mandate to the effect that it administers its duties "efficiently, fairly and in accordance with the law." ${ }^{88}$

Finally, the Segal Report recommends that Justice Canada publish more information about extradition processes generally, including "statistics about extradition cases" and "the policies and procedures that guide decision-making by counsel within the IAG." ${ }^{189}$ Transparency, Mr. Segal felt, would help to combat public ignorance and suspicion. ${ }^{190}$ I would echo this call but add an additional rationale: more information would

186

187

MM, supra note 9 at para 1.

This is what happens, formally speaking. See Weinstein \& Dennison, supra note 33 at 217-18.

See the Board's website: Immigration and Refugee Board of Canada (Ottawa: IRBC, last modified 26 January 2021), online: <irb-cisr.gc.ca/en/Pages/index.aspx> [perma.cc/V7 7J-3VVM].

89 Segal Report, supra note 16 at 107. Not long before the Segal Report was released, the IAG did publish statistics on extradition between Canada and the US. See Canada, Department of Justice, Extradition Fact Sheet: Statistics on requests from the United States (Ottawa: DOJ, last modified 1 March 2019), online: <www.justice.gc.ca/eng/cj-jp/emlaeej/stat.html> [perma.cc/W42J-PMN2].

Segal Report, supra note 16 at 107. 


\section{MANITOBA LAW JOURNAL}

assist Canadians in understanding the actual policies and practices which are in place and allow us to ask the tougher questions about whether they serve adequately to protect persons sought, especially in cases like Diab where, as the record shows, a wrongful extradition was actively sought and is not regretted by those who sought it.

\section{CONCLUSION}

While attending a criminal law conference some years ago, I struck up a conversation with a federal litigator whom I knew to have worked on some extradition cases. When I brought up an interesting issue that had arisen in a couple of recent cases, the lawyer's response was to smile and say (condescendingly, if truth be told), "Ah, academics hate extradition."

Suffice it to say, this seems like a misplaced opinion. "Academics" and indeed many other will know that extradition is one of the most important tools to suppress transnational crime. Given the increasing presence and intrusiveness of cross-border and even globalized criminal activity, it is important for Canada to be an effective and enthusiastic participant in inter-state cooperation efforts. We need an effective extradition system, and I should not be heard to suggest otherwise.

However, it is equally important that our extradition system be procedurally fair and sufficiently protective of the rights of individuals caught up in it, including, but not limited to, Canadian citizens who are sought by foreign states for prosecution. As this paper has demonstrated, there are serious problems on both fronts. Hassan Diab's case, in particular, powerfully makes the case that significant changes are needed in order to prevent wrongful extradition. I have argued here that: the committal process, while it seems consistent with Parliament's design, is not Chartercompliant and dissatisfactory on a number of fronts; and the role of the IAG should be re-thought and restructured.

Currently, we are living with the Prime Minister's apparently broken promise to usher in change that will prevent a re-occurrence, IAG's insistence that there are no problems with the current system, and courts which are deferential to the status quo. It appears that public attention and Parliamentary scrutiny are the next logical steps to enact meaningful change, and it is past time that we had more of both. 